\title{
Climatic reconstruction at the Sannai- Maruyama site between Bond events 4 and 3 -implication for the collapse of the society at 4.2 ka event
}

\author{
Hodaka Kawahata
}

\begin{abstract}
The Jōmon period/culture corresponds to the Neolithic period/culture in Japanese prehistory. The Sannai-Maruyama site (5.9-4.2 cal. kyr BP), the most famous, the largest, and the well-studied mid-Holocene (mid-Jōmon) archeological site inhabited by hunter-gatherers with sedentary lifestyle in northern Japan, started at early Bond event 4 and collapsed at late Bond event 3 (4.2 cal. kyr BP at the boundary between mid-Holocene, Northgrippian, and lateHolocene, Meghalayan), synchronous with the decline of the north Mesopotamian civilization and the Yangtze River civilization in China. Alkenone sea surface temperatures (SSTs), a proxy for early-midsummer SSTs, generally suggest that the early-midsummer SSTs (and atmospheric temperatures (ATs)) at 41 $00^{\prime} \mathrm{N}, 140^{\circ} 46^{\prime} \mathrm{E}$, about 20 $\mathrm{km}$ north to the Sannai-Maruyama site, located in Aomori Prefecture, peaked around 4.8-4.3 cal. kyr BP and showed minima at 5.9 and $4.1 \mathrm{cal}$. kyr BP. In spite of some discrepancy in short periods, this feature is consistent with that estimated from the assemblages of Ostracodas. $\delta^{18} \mathrm{O}$ value of benthic foraminifera of Nonionellina labradorica and Nonionella stella, alkenone production flux, and pollen assemblages could reflect annual-based temperature, which generally suggests that the climate was warmer at 6.0-4.2 cal. kyr BP, which could show the warmer environments at 6.0-5.0 cal. than expected from alkenone SST in early-midsummer. Overall, northward shift of the westerly jet, in association with a strengthened East Asian Summer Monsoon, could cause a relatively warm climate around 6.0-4.3 cal. kyr BP, when the Sannai-Maruyama site flourished. High food production density, by effective hansaibai (selective preservation or growth) in Castanea- and Aesculus-dominated forests, up to one sixth of the rice production density, could have supported high population density, resulting large community at the Sannai-Maruyama site. Cooling episode at $4.2 \mathrm{cal}$. kyr BP could have resulted in the decline of chestnut hansaibai, leading to the collapse of the site. Recent results from a compiled archeological site map suggested no large decline of the population but, instead, a dispersal to the surrounding area at $4.2 \mathrm{cal}$. kyr BP. It is consistent with ancestral population dynamics for the descendent from Jōmon people, in contrast to those from the immigrants from Far East Asia to the Japanese Archipelago with paddy rice cultivation technology after $2.9 \mathrm{cal}$. kyr BP, based on modern Japanese molecular sequences.
\end{abstract}

Keywords: 4.2 ka event (Northgrippian/Meghalayan boundary), Asian Summer Monsoon, Mitochondrial DNA haplogroup, Alkenone, Hunter-fisher-gatherer, Jōmon, Yayoi, Bond event 3

Correspondence: kawahata@aori.u-tokyo.ac.jp

Atmosphere and Ocean Research Institute, The University of Tokyo,

Kashiwanoha 5-1-5, Kashiwa, Chiba 277-8564, Japan 


\section{Introduction}

\section{Background}

The post-glacial period of the last $11.7 \mathrm{kyrs}$, the Holocene, is characterized by the worldwide expansion of Homo sapiens and the development of civilizations, the oldest of which developed in eastern Africa around $200 \mathrm{kyrs}$ ago (e.g., McDougall et al. 2005). It has been proposed that the Holocene can be sub-classified into Early, Middle, and Late stages, with an Early-Middle Holocene Boundary at 8.2 cal. kyr BP and a Middle-Late Holocene Boundary at 4.2 cal. kyr BP, by a Working Group of INTIMATE (International Commission on Stratigraphy). Each stage is linked to a Global Stratotype Section and Point (Walker et al. 2012). The former and latter boundaries generally correspond to Bond event 5 and late Bond event 3, respectively, since the Holocene climate was largely stable, but fluctuated appreciably with a cycle of $1500 \pm 500$ years (Bond et al. 2001). Especially, the Middle-Late Holocene boundary at $4.2 \mathrm{cal}$. kyr BP receives much attention because it coincides with a cultural shift caused by a global climate event.

Pottery is generally accepted as the main criterion for the Neolithic Epoch in the hunter-fisher-gatherer continuum of East Asian prehistory, where pottery preceded agriculture by several millennia. In contrast, plant and animal husbandry developed prior to the emergence of pottery in the Near East, while pottery and agriculture appeared almost simultaneously in Europe (Kuzmin 2006). The earliest known class of pottery decorated with cord-pattern (jömon) reliefs and stone arrowheads was produced during the coldest period of northernmost Honshu, Japan (Fig. 1a), around $16.0 \mathrm{cal}$. kyr BP (e.g., Nakamura et al. 2001; Kawahata et al. 2017a), when the Jōmon culture, the earliest major prehistoric Japanese culture, originated (Habu 2004). Among the best-known and most-studied mid-Holocene Jōmon archeological sites is the Sannai-Maruyama site in northernmost Honshu, Japan (Sannai Maruyama special historical site; http://sannaimaruyama.pref.aomori.jp/english/) (Fig. 1a, b). This site is particularly reputed for the exceptionally large permanent settlement $\left(0.42 \mathrm{~km}^{2}\right)$, larger than any other hunter-fishing-gatherer settlement of the 90,531 known Jōmon sites (The Agency for Cultural Affairs of the Japanese Government 2014;https://www.nabunken.go. jp/nabunkenblog/2014/06/tanken23.html; JOMON JAPAN; https://jomon-japan.jp/en/). It is highly likely that hansaibai (selective preservation or growth) of the Castanea crenata (chestnuts) and Aesculus turbinate (horse chestnuts) trees

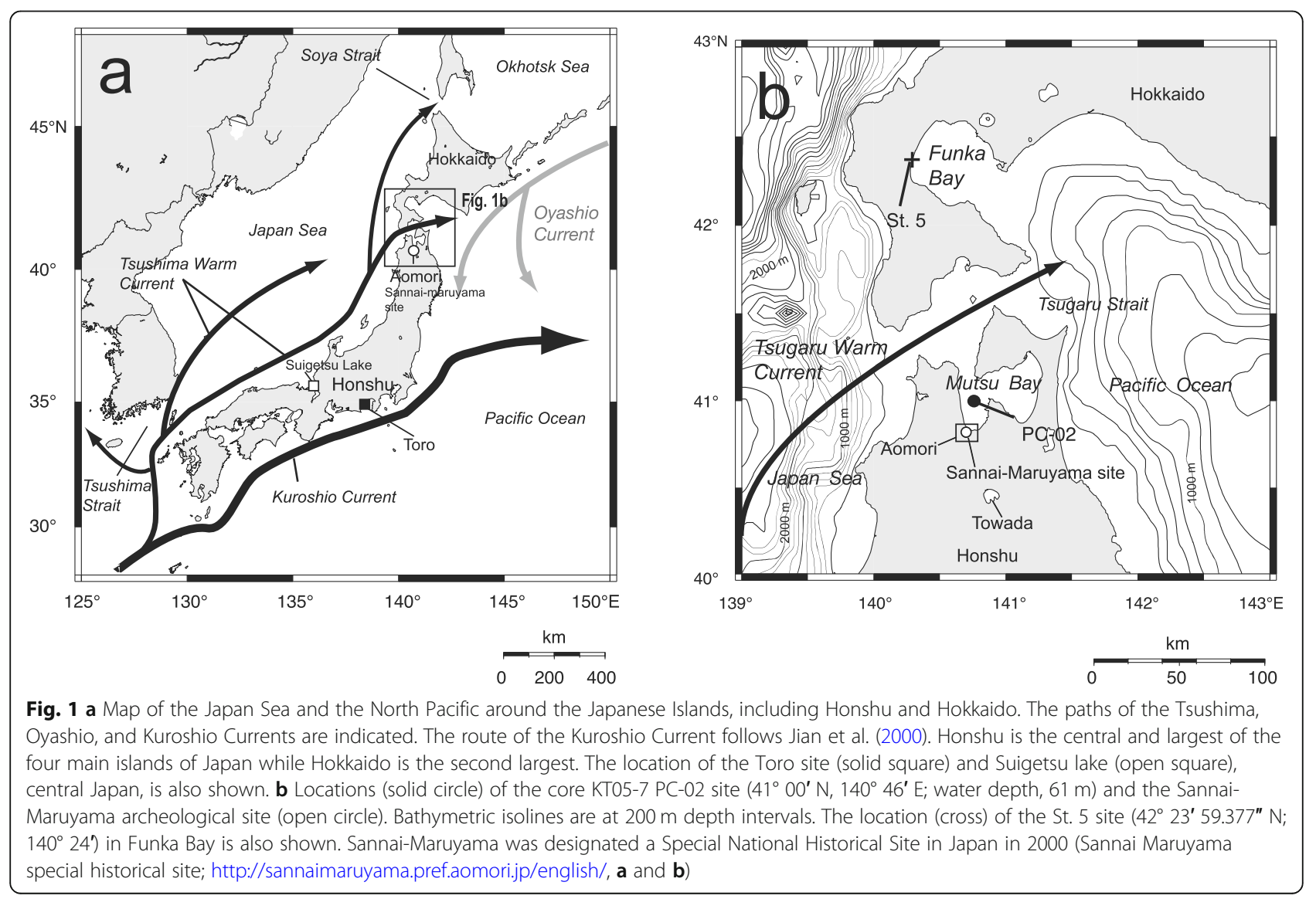


was adapted as a food source to support the large population, although it has also been suggested that such agriculture was never introduced in the Jomon period in Japan (Nakao 1976; Kitagawa and Yasuda 2004). Occupation of the site began around $5.9 \pm 0.1 \mathrm{cal}$. kyr BP (coinciding with early Bond event 4), soon after the eruption of the Towada volcano (Fig. 1b) at $6.0 \mathrm{cal}$. kyr BP. It expanded to include many large communities and reach its population maximum at 5.2-5.0 cal. kyr BP. Some archeological researches have revealed that the Jomon people extended the exploitation of plant food and marine resources and even carried out some management of environments and species (e.g., Tsuji 2001; Sato and Ishikawa 2004; Habu and Hall 2013). As a result, the organizational complexity in subsistence and settlement, reaching its high point with the population size, was suggested to have undergone significant expansion. Nonetheless, the community collapsed around $4.2 \pm$ 0.1 cal. kyr BP (Habu 2004, 2008), at late Bond event 3, coinciding with a sudden cooling by $2.0^{\circ} \mathrm{C}$ induced by the change of the East Asian Summer Monsoon (EASM) (Fig. 2a, b) (Kawahata et al. 2009b; Kariya et al. 2016). Around this time, it was also reported that Suigetsu Lake, on the Japanese coast, about $700 \mathrm{~km}$ from the SannaiMaruyama site, received frequent heavy rainfall (Fig. 1a) (Suzuki et al. 2016; Suzuki 2017). The Sannai-Maruyama site then remained uninhabited until the early warm Heian Period (nine to tenth century $\mathrm{AD}$ ), great flourishing period in Japanese culture from literature to paintings (Sannai Maruyama special historical site; http://sannaimaruyama. pref.aomori.jp/english/) (Kawahata et al. 2017a, b).

Concomitantly, Sumer, arguably the first urban civilization in the world, emerged in southern Mesopotamia during the Uruk period (5.9 cal. kyr BP), located on the floodplain of the lower reaches of the Tigris and Euphrates rivers (Chandler 1987). At the same time, a North Atlantic cooling episode from ice-rafted debris at $5.9 \mathrm{cal}$. kyr BP caused one of the most intense Holocene aridification events in this region (Bond et al. 1997). The initial desiccation appeared in the Sahara at 5.9 cal. kyr BP, after previously humid conditions from 10.0 to 6.0 cal. kyr BP. This may have triggered events leading to the Early Dynastic period of ancient Egypt (Malville et al. 1998; Jolly et al. 1998; Claussen et al. 1999). Another important boundary at $4.2 \mathrm{cal}$. kyr BP occurred when an abrupt change to a cold and dry climate significantly influenced the collapse of the Neolithic culture in the Gansu-Qinghai region of China (Liu et al. 2010). Drought was widespread at $4.2 \mathrm{cal}$. kyr BP across Egypt and much of Africa, and this event may have been caused by weak monsoons induced by a change in the circulation of the North Atlantic (e.g., Gasse 2000). The episode led to its current climate and resulted in a temporary collapse of Egyptian civilization during pyramid building in the Old Kingdom. Droughts and fires plagued the region, causing famine and social unrest at $4.2 \mathrm{cal}$. kyr BP (Stanley et al. 2003; Riel 2008). The Uruk period existed from the protohistoric Chalcolithic to Early Bronze Age period in the history of Mesopotamia (6.05.2 cal. kyr BP). In this area, the Akkadian Empire (4.3$4.15 \mathrm{cal}$. kyr BP) was the first ancient empire and prosperous country. However, this aridification was very likely to have also caused the collapse of the Akkadian Empire in Mesopotamia around $4.2 \mathrm{cal}$. kyr BP (e.g., Parker et al. 2006). It has been proposed that its onset could have resulted from the cooling event in the North Atlantic, known as Bond event 3 (Alley and Ágústsdóttirab 2005). All these cultures experienced a major population decrease at approximately the same time due to aridification, often associated with cold climates (Walker et al. 2012), and generally similar to that estimated in Japan (Fig. 3b) (Biraben 1993, 2005; Kito 2000).

\section{Problematic}

Temperature is one of the most important environmental parameters. Alkenone sea surface temperatures (SST) and Ostracoda assemblages suggest warmer environments in the latter half of the period, between early Bond event 4 and late Bond event 3 in Mutsu Bay (Kawahata et al. 2009b; Irizuki et al. 2015). In contrast, the relative abundance of Castanea suggests colder environments in the same period (Fig. 2h). Chestnuts and horse chestnuts were important food for the Jomon people, and it has been proposed that they were protected by hansaibai (derived from han and Saibai, i.e., half cultivation) (Nakao 1976; Kitagawa and Yasuda 2004). The northern limit of the distribution of Castanea, controlled by atmospheric temperature, is located in northernmost Honshu. Chestnut production was affected strongly by warmth of the climate or the relevant weather (Kitagawa and Yasuda 2004). Food availability and diversity, influenced by the climate, might, therefore, have controlled the prosperity/collapse of the site (Habu and Hall 2013). Although hunter-fisher-gatherers generally prefer an unsettled life, the large settlement size at Sannai-Maruyama suggests that a population center existed here for some time. After its collapse at $4.2 \mathrm{cal}$. kyr BP, there is a contention as to whether these people died out at late Bond event 3 or dispersed to smaller villages without significant overall population change in the Aomori Plain (Fig. 3b, c) (Sekine 2014).

\section{Objective}

The change in climate known as the $4.2 \mathrm{ka}$ event (e.g., deMenocal 2001; Walker et al. 2012), corresponding to late Bond event 3 , has received much attention because it is the boundary of the mid-Holocene (Northgrippian) and late-Holocene (Meghalayan) defined by the International Commission on Stratigraphy in July 2018 and 


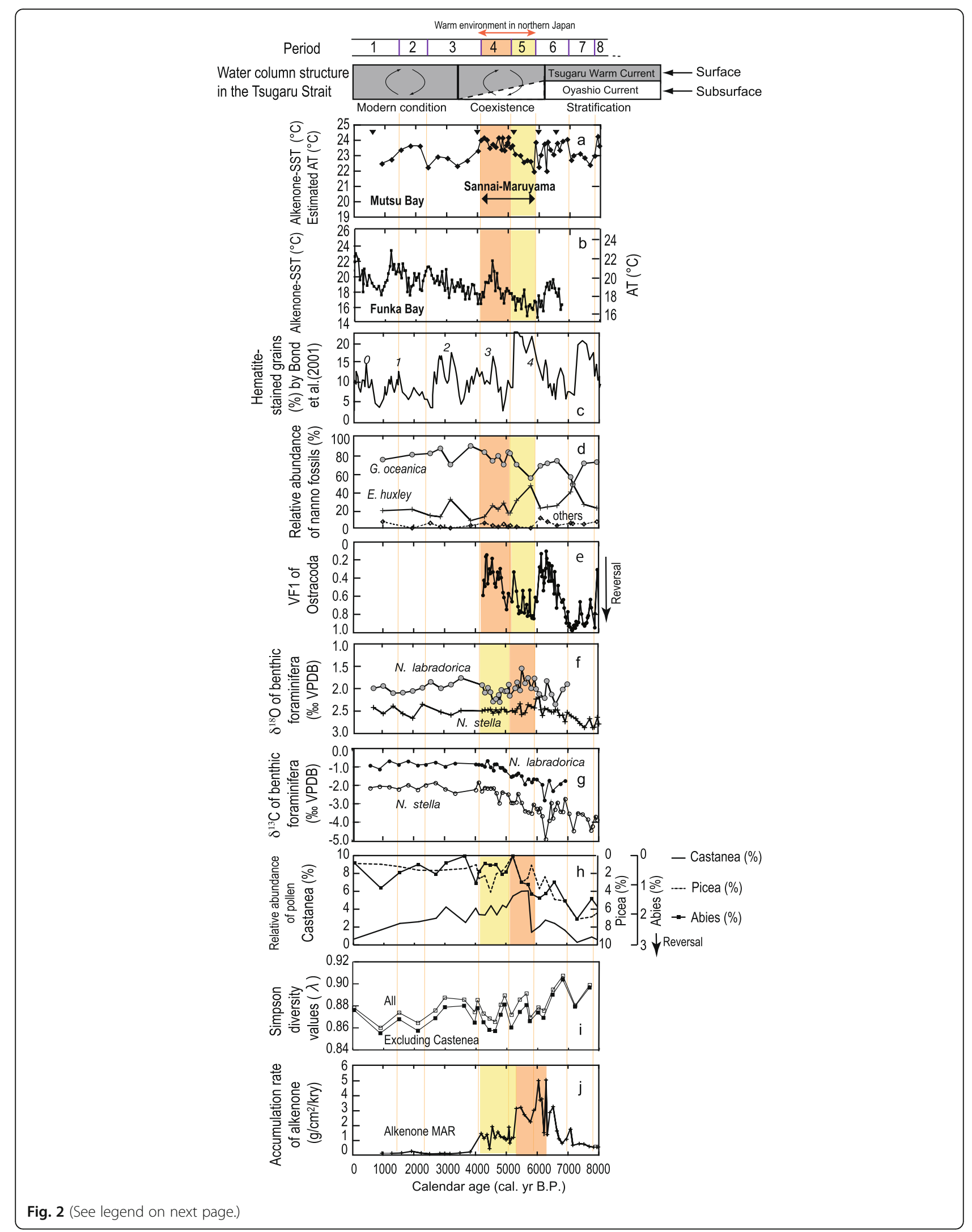


(See figure on previous page.)

Fig. 2 Time series records of a alkenone SSTs and estimated ATs in Mutsu Bay with age-controlling points represented in solid reversed triangles (Kawahata et al. 2009b); b alkenone SSTs and ATs at St. 5 Funka Bay (Kawahata 2017); c content of hematite-stained grains as drift ice indices in the north Atlantic with the number of Bond events (Bond et al. 1997); $\mathbf{d}$ relative abundances of Emiliania huxleyi and Gephyrocapsa oceanica; $\mathbf{e}$ the first factor (VF1) of ostracods (Irizuki et al. 2015); $\mathbf{f} \delta^{18} \mathrm{O}$ values of benthic foraminifera (Nonionella stella (Cushman) and Nonionellina labradorica (Dawson)); $\mathbf{g} \delta^{13} \mathrm{C}$ values of benthic foraminifera (N. stella (Cushman) and N. labradorica (Dawson)); $\mathbf{h}$ relative abundances of Castanea, Picea, and Abies (Kawahata et al. 2009b); i Gini-Simpson index for pollen (upper: including Castenea, lower: excluding Castenea); and $\mathbf{j}$ accumulation rate of alkenone (Kawahata et al. 2009b). In the upper column, periods are classified based on the SST: periods 8 (8.3-7.9 cal. kyr B.P.), 6 (7.0-5.9 cal. kyr B.P.), 4 (5.1-4.1 cal. kyr B.P.), and 2 (2.3-1.4 cal. kyr B.P.) were characterized by warm alkenone SSTs with mean values of 23.4, 23.4, 23.8, and $23.5^{\circ} \mathrm{C}$, respectively. In contrast, periods 7 (7.9-7.0 cal. kyr B.P.), 5 (5.9-5.1 cal. kyr B.P.), and 3 (4.1-2.3 cal. kyr B.P.) were characterized by cold alkenone SSTs with mean values of $21.6,22.8,22.9$, and $22.7^{\circ} \mathrm{C}$, respectively (Kawahata et al. 2009b). Orange and yellow shadings represent very and relatively warm environments, respectively, after the sea level was stabilized around 6.2 cal. kyr BP. The water-column structure of the Tsugaru Strait as reconstructed by Kuroyanagi et al. (2006) is shown in the second column. During 9.0-6.2 cal. kyr BP, the intensity of the Tsugaru Warm Current (TWC) was weak and the subsurface water remained under the influence of the cold Oyashio Current. The modern oceanographic regime was established at $6.2 \mathrm{cal}$. kyr BP, when the subsurface waters began to warm as a result of the enhanced flow rate of the TWC. Only TWC flows along the Tsugaru Straight since $3.4 \mathrm{cal}$. kyr BP. Light gray shading represents water influenced by warm currents

has been cited as a plausible explanation for the collapse of major ancient civilizations in Egypt, the Indus Valley, and Mesopotamia (Cullen et al. 2000; Stanley et al. 2003; Staubwasser et al. 2003). However, the causal factors behind them remain ambiguous. In this paper, the climatic/environmental fluctuation between early Bond event 4 and late Bond event 3 in northern Japan is estimated using new data for the stable isotopic compositions of benthic foraminifera and the relative abundance of coccoliths, as well as by re-evaluation of previously published, but unexamined, Ostracoda and pollen data and alkenone accumulation rate. Within this framework, the relationship between the density of food production and the prosperity/collapse of the site in association with climate change-influenced "hansaibai" can be discussed. Finally, the possibility of population dispersion to smaller villages is evaluated following the collapse of the main community at the Sannnai-Maruyama site.

\section{Study area and materials}

\section{Study area and sediment samples}

Mutsu Bay is located in northernmost Honshu, Japan, and is a shallow (mean depth, $40 \mathrm{~m}$ ) bay measuring $1668 \mathrm{~km}^{2}$ with a relatively flat floor (gradient $<2^{\circ}$ ) (Ministry of the Environment; https://www.env.go.jp/water/ heisa/heisa_net/waters/mutuwan.html). It opens into the Tsugaru Strait (sill depth, $130 \mathrm{~m}$ ) that connects the Japan Sea with the northwestern North Pacific (Fig. 1b). Monthly SSTs are $6-7^{\circ} \mathrm{C}$ in February to March and 22$24^{\circ} \mathrm{C}$ in August to September, with an annual mean SST of $15{ }^{\circ} \mathrm{C}$ (Japan Meteorological Agency; https://www. data.jma.go.jp/gmd/kaiyou/data/db/kaikyo/series/engan/ engan130.html). During November to March, the uniform vertical profile reflects strong vertical mixing of the water column. The salinity is $32.0-33.6$ at the surface and 33.2-34.0 at a depth of $30 \mathrm{~m}$, because only small riverine fluxes enter Mutsu Bay. The salinity is, thus, comparable to that of the Tsugaru Strait (32.0-34.6)
(Automatic monitoring system in Mutsu Bay; http:// www.mutsuwanbuoy.jp/observation/).

The warm Tsugaru Current is the main branch of the Tsushima Current and significantly influences the oceanographic setting of Mutsu Bay and the Tsugaru Strait (Fig. 1a). The Sea of Japan was isolated from the open ocean during glacial times due to the $130 \mathrm{~m}$ sill depth of the Tsugaru Strait (Takei et al. 2002). It has experienced different ocean environments in response to glacialinterglacial cycles (e.g., Sagawa et al. 2018; Tada et al. 2018; Irino et al. 2018). Rising sea levels established the modern oceanographic regime at $6.2-3.4 \mathrm{cal}$. kyr BP, when subsurface waters began to warm as a result of the enhanced flow rate of the Tsushima Current (Kuroyanagi et al. 2006).

The entire $865 \mathrm{~cm}$ length of the piston core PC-02 was collected at $61 \mathrm{~m}$ water depth at $41^{\circ} 00^{\prime} \mathrm{N}, 140^{\circ} 46^{\prime} \mathrm{E}$ (Fig. 1b) during cruise KT05-7 of the R/V Tansei. The core consists of very dark, greenish gray, homogeneous clay-grade sediment from the surface to $786 \mathrm{~cm}$. One thin sand layer at $606-596 \mathrm{~cm}$ contains burrows, scattered mollusk shells, and sea urchin fragments. The sediments are comprised of very dark, grayish brown sandy silt or silt intercalated with sand layers from 786 to $855 \mathrm{~cm}$ and dark, olive gray, coarse sand below $855 \mathrm{~cm}$, possibly representing dispersed ash layers (Kawahata et al. 2009b; Scudder et al. 2016).

Recent meteorological data (1981-2010) collected at Aomori City $\left(40^{\circ} 49^{\prime} \mathrm{N}, 140^{\circ} 45^{\prime} \mathrm{E}\right.$, about $20 \mathrm{~km}$ south of the core site) show that monthly mean ATs have fluctuated between $-1.2^{\circ} \mathrm{C}$ (January) and $23.3^{\circ} \mathrm{C}$ (August), with an annual and summer (June to September) mean ATs of $10.4{ }^{\circ} \mathrm{C}$ and $20.2^{\circ} \mathrm{C}$, respectively (Japan Meteorological Agency; http://weather.time-j.net/Climate/Chart/ aomori). Average annual rainfall is $1290 \mathrm{~mm}$, and the average annual duration of solar irradiation is $1687 \mathrm{~h}$. The land is covered with snow for approximately 120 days each year. The prevailing wind direction is from the southwest except in June (when winds come from the 


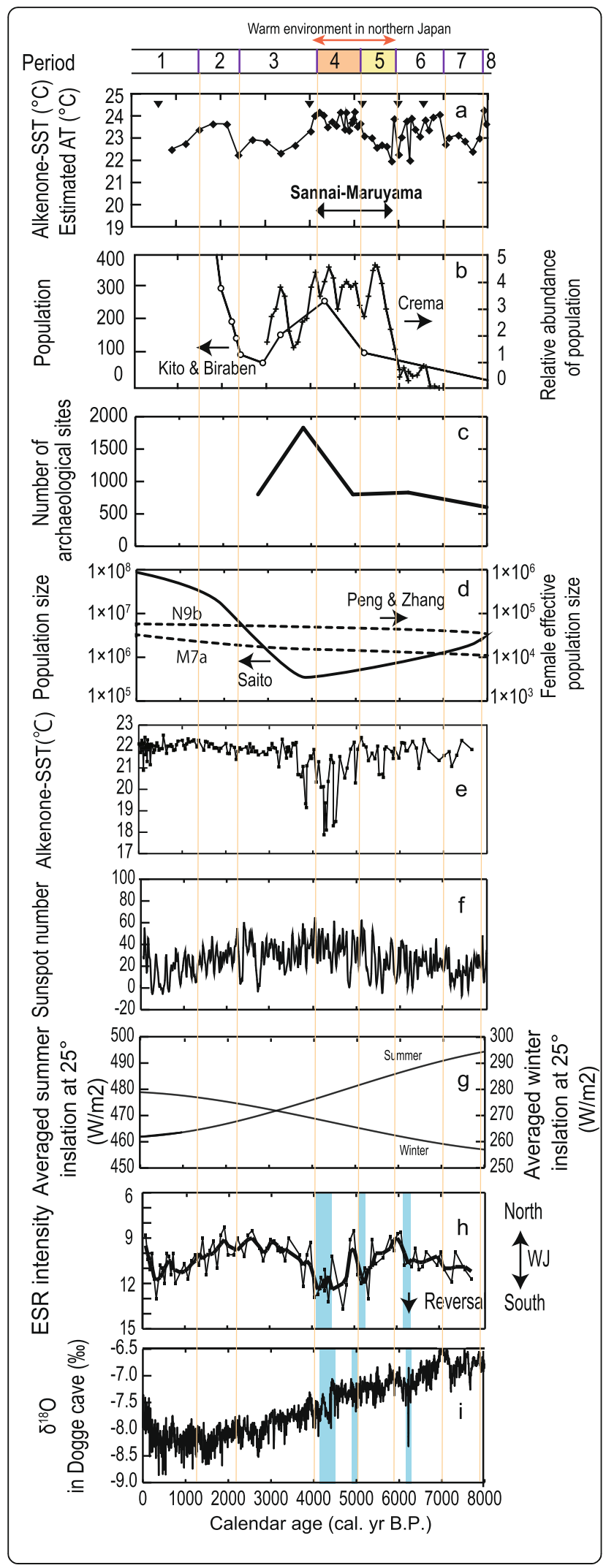

Fig. 3 Time series records of a alkenone SSTs and estimated ATs in Mutsu Bay with age-controlling points represented in solid reversed triangles (Kawahata et al. 2009b); b population (open circle) estimated by Kito $(2000)$ and Biraben $(1993,2005)$ and the relative abundance of population at Jōmon sites (+) (Crèma et al. 2016); c number of archeological sites in Aomori (Sekine 2014); $\mathbf{d}$ relative population size of total Japanese people (solid line) by Saito (2017) and relative female effective population size (dotted line) of mitochondrial DNA haplogroups N9b and M7a, estimated by Peng and Zhang (2011); e alkenone SSTs at MD06-3050 (27 $43.36^{\prime} \mathrm{N}, 121^{\circ}$ $46^{\prime} 88 \mathrm{E}$ ) in the inner shelf of the East China Sea, off river mouth of the Yangtze river (Kajita et al. 2018); $\mathbf{f}$ sunspot numbers (Usoskin et al. 2007); $\mathbf{g}$ the summer and winter daily insolation at $55^{\circ} \mathrm{N}$ in the Northern Hemisphere for the last 8000 years $\left(\mathrm{W} \mathrm{m}^{-2}\right)$ (Berger 1978); and $\mathbf{h}$ ESR intensity of fine silt-sized quartz particles in Japan Sea sediments (Nagashima et al. 2013), which is a proxy for the latitudinal shift of westerly jet stream, related to latitudinal shift of the East Asian Monsoon. Thin and thick lines indicate original data and the 3-point running mean, respectively. $\mathbf{i} \delta^{18} \mathrm{O}$ of the Dongge Cave stalagmites as a proxy for the intensity of the Far Eastern Asian Summer Monsoon (Wang et al. 2005). Blue color shadings between Bond events 4 and 3 in $\mathbf{h}$ and $\mathbf{i}$ represent southward shift of westerly jet and weaker summer monsoon, respectively

north-northwest) and July (when winds come from the north).

\section{The Sannai-Maruyama archeological site}

The Jōmon period (16.50-2.90 cal. kyr BP; hunter-fishergatherer period), based on analysis of the earliest known Jōmon pottery (Habu 2004, 2008; Kosugi et al. 2009), constitutes Japan's Neolithic period. "Jōmon" pottery is characterized by ceramics produced in an outdoor bonfire at a temperature of not more than approximately $900^{\circ} \mathrm{C}$. The Sannai-Maruyama site, located approximately $3 \mathrm{~km}$ south of Mutsu Bay $\left(40^{\circ} 49^{\prime} \mathrm{N}, 140^{\circ} 42^{\prime} \mathrm{E}\right.$; altitude, 17-20 m; Fig. 1b), has been extensively excavated, uncovering large pit-dwellings, adult burial pits, burial jars for children, the remains of buildings supported by large and medium sized pillars, and numerous remains of animals and plants; no weapons have been found (Aomori Prefecture 2002). This evidence indicates that the site was permanently occupied by a large population with a well-developed culture. Although the Jomon people are considered to have been semi-sedentary and collected food by hunting, fishing, and gathering, a few plant types, including chestnuts and horse chestnuts, were cultivated by hansiabai to support the large population (Kitagawa and Yasuda 2004). In the hansaibai phase, people did not plant seeds intentionally, but rather, extensive stands were developed by protecting trees from cutting (Nakao 1976).

Based upon the number of sites and houses, the first order estimates of the total population in Japan are $\sim 20$, 000 in the early Jomon ( 8.0 cal. kyr BP), 260,000 in the middle Jomon ( $5.0 \mathrm{cal}$. kyr BP), and 80,000 in the late Jōmon (2.5 cal. kyr BP) (Biraben 1993, 2005; Kito 2000) (Fig. 3c). Crèma et al. (2016) compiled many ${ }^{14} \mathrm{C}$-dated 
population proxies and tried to estimate population dynamics in the Aomori area, suggesting a rapid exponential increase between 6.0 and $5.5 \mathrm{cal}$. kyr BP, followed by a high density with some fluctuation between 5.5 and $4.1 \mathrm{cal}$. kyr BP and a decline with a large trough at 3.70 cal. kyr BP (Fig. 3b).

\section{Analytical procedures}

Methods of accelerator mass spectrometry radiocarbon dating are described in Kawahata et al. (2009b). The use of marine shells requires the additional consideration of reservoir age; however, this study estimated the age control without the residual reservoir age $(\Delta R)$ because Mutsu Bay is almost entirely isolated from the open ocean. $\Delta \mathrm{R}$ from the Tsugaru Strait was estimated to be $34 \pm 42$ years (Yoneda et al. 2007). Raw ${ }^{14} \mathrm{C}$ data from shells were converted to calendar ages using the latest version of the Marine13 database (Reimer et al. 2013) and the OxCal 4.2.3 program (Ramsey 2009), the results of which are listed in Table 1.

Benthic foraminifera were used for stable isotope measurements due to the low occurrence of planktic foraminifera. Thirty specimens of Nonionellina labradorica (Dawson) and 40-50 specimens of Nonionella stella (Cushman) were collected. The detailed procedure for their study is as reported in Ohkushi et al. (2003). Analyses were conducted with an IsoPrime mass spectrometer fitted with an on-line automated carbonate preparation device (Micromass UK) found at the Geological Survey of Japan, National Institute of Advanced Industrial Science and Technology. The analytical precision of this system was better than $0.03 \%$ for $\delta^{13} \mathrm{C}$ and $\delta^{18} \mathrm{O}$ (Ohkushi et al. 2003) (see Table 2). Sample gases were calibrated for every run using the US National Institute of Standards and Technology calcite standard (NBS-19) and are reported as the per-mil deviation relative to the Vienna Pee Dee Belemnite standard. Quantitative estimates of summer AT based on the high correlation between AT and alkenone SST are available in Mutsu and Funka Bays with analytical errors of $0.3^{\circ} \mathrm{C}$.

Pollen and spores were analyzed by the method of Kawahata and Ohshima (2002). To calculate the relative abundance of pollen and spores in sediments (grains $\left.\mathrm{g}^{-1}\right), \sim 1 \mathrm{~g}$ of a freeze-dried aliquot was weighed, and then, $10 \% \mathrm{HCl}$ was added to dissolve carbonates followed by HF treatment to remove siliceous matter. After density separation with $\mathrm{ZnBr}_{2}$, the samples were treated by Erdtman's acetolysis method and with 10\% $\mathrm{NaOH}$. Microfossil slides of the treated material were prepared by mounting in glycerin jelly. The palynological analyses were carried out under a Nikon Optiphot-2 microscope at magnifications of $\times 150$ and $\times 600$. At least 253 grains (380 grains on average) of pollen and spores were counted for each sample. Percentage values of each taxon were calculated in relation to the sum of the arboreal and nonarboreal (shrub and herb) pollen. A diversity index is a quantitative measure that reflects how many different species types are present in a particular pollen dataset. The Gini-Simpson index for pollen was calculated in core PC-02 (e.g., Gini 1912; Simpson 1949).

\section{Results and discussion}

Early-midsummer temperature in Mutsu and Funka Bays around 5.9-4.2 cal. kyr BP

Our discussion on SST focuses mainly on the period during which the Sannai-Maruyama site flourished (around Bond events 4-3) (Table 2). Alkenone SSTs record earlymidsummer SSTs, when the highest biogenic production occurs around northern Japan (Takahashi et al. 1995; Kawahata et al. 2009a). Since paleo-SST was recently reconstructed at St. 5 in Funka Bay (Kawahata 2017), located on the opposite side of the Tsugaru Strait (Kawahata 2017), the SST can be evaluated for northernmost Honshu and southernmost Hokkaido, where many northern

Table 1 Sampled species, core depths, and results of radiocarbon dating

\begin{tabular}{|c|c|c|c|c|c|}
\hline Sample type & Specific name & Sample no. & Depth $(\mathrm{cm})$ & ${ }^{14} \mathrm{C}$ age (yrs BP) & $\begin{array}{l}\text { Calendar age } \\
\text { (cal. yrs BP) }\end{array}$ \\
\hline Mollusca & Mizuhopecten yessoensis (Jay) & $1-2$ & 3.3 & $1080 \pm 80$ & $630 \pm 70$ \\
\hline Mollusca & Mizuhopecten yessoensis (Jay) & $2-6$ & 27.5 & $4030 \pm 100$ & $4051 \pm 144$ \\
\hline Benthic foraminifera & Mixed species & $2-6$ & 27.5 & $4170 \pm 90$ & $4259 \pm 126$ \\
\hline Mollusca & Leionucula tenuis (Montagu) & $2-43$ & 111.5 & $4930 \pm 90$ & $5263.5 \pm 141$ \\
\hline Mollusca & Ringiculina doliaris (Gould) & $3-28$ & 177.4 & $5600 \pm 110$ & $6016.5 \pm 127$ \\
\hline Benthic foraminifera & Mixed species & $3-28$ & 177.4 & $5610 \pm 100$ & $6017.5 \pm 117$ \\
\hline Mollusca & Mizuhopecten yessoensis (Jay) & $4-15$ & 248.6 & $6160 \pm 120$ & $6591 \pm 140$ \\
\hline Mollusca & Mercenaria stimpsoni (Gould) & $5-39$ & 403.9 & $7830 \pm 110$ & $8283 \pm 109$ \\
\hline Mollusca & Raetellops pulchellus (Adams \& Reeve) & $8-6$ & 633.9 & $9450 \pm 90$ & $10,301.5 \pm 106$ \\
\hline Mollusca & Macoma cf. tokyoensis (Makiyama) & $8-25$ & 674.5 & $9490 \pm 90$ & $10,342.5 \pm 113$ \\
\hline
\end{tabular}


Table 2 Sampled core depths; ages; sea surface temperatures (SST); fluxes of C37 benthic foraminifera; relative abundance of pollens including Castanea, Abies, and Picea; and relative abundance of coccoliths

\begin{tabular}{|c|c|c|c|c|c|c|c|c|c|c|c|}
\hline \multirow{2}{*}{$\begin{array}{l}\text { Sample } \\
\text { no. }\end{array}$} & \multirow{2}{*}{$\begin{array}{l}\text { Depth } \\
(\mathrm{cm})\end{array}$} & \multirow{2}{*}{$\begin{array}{l}\text { Age } \\
\text { (cal. } \\
\text { yrs } \\
\text { BP) }\end{array}$} & \multirow{2}{*}{$\begin{array}{l}\mathrm{C}_{37} \\
\text { alkenone } \\
\mathrm{SST}\left({ }^{\circ} \mathrm{C}\right)\end{array}$} & \multirow{2}{*}{$\begin{array}{l}\mathrm{C}_{37} \\
\text { alkenone } \\
\text { flux ( } \mathrm{Mg} \\
\mathrm{Cm}^{-2} \\
\left.\mathrm{kyr}^{-1}\right)\end{array}$} & \multicolumn{2}{|c|}{ N. labradorica } & \multicolumn{2}{|l|}{ N. Stella } & \multirow{2}{*}{$\begin{array}{l}\text { Gephyrocap } \\
\text { oceanica } \\
(\%)\end{array}$} & \multirow{2}{*}{$\begin{array}{l}\text { Emiliania } \\
\text { huxleyi } \\
(\% 0)\end{array}$} & \multirow{2}{*}{$\begin{array}{l}\text { The other } \\
\text { coccoliths } \\
(\%)\end{array}$} \\
\hline & & & & & $\delta^{18} \mathrm{O}(\% 0)$ & $\overline{\delta{ }^{13} \mathrm{C}(\% 0)}$ & $\overline{\delta^{18} \mathrm{O}(\%)}$ & $\overline{\delta{ }^{13} \mathrm{C}(\%)}$ & & & \\
\hline & 3.3 & 0.63 & & & 1.99 & -0.94 & 2.42 & -2.16 & & & \\
\hline $1-3$ & 5.5 & 0.95 & 22.5 & 0.12 & 1.94 & -1.14 & 2.56 & -2.08 & 74.3 & 18.9 & 6.8 \\
\hline $1-4$ & 7.7 & 1.27 & 22.7 & 0.12 & 2.10 & -0.70 & 2.39 & -2.10 & & & \\
\hline $1-5$ & 9.9 & 1.59 & 23.4 & 0.14 & 2.09 & -0.89 & 2.56 & -2.23 & & & \\
\hline $1-6$ & 12.1 & 1.91 & 23.6 & 0.25 & 2.05 & -0.71 & 2.66 & -2.00 & 79.7 & 20.3 & 0 \\
\hline $1-7$ & 14.3 & 2.23 & 23.6 & 0.13 & 1.98 & -0.93 & 2.35 & -2.25 & & & \\
\hline $2-1$ & 16.1 & 2.50 & 22.2 & 0.08 & 1.85 & -0.89 & & -2.01 & 81.1 & 13.5 & 5.4 \\
\hline $2-2$ & 18.4 & 2.83 & 22.9 & 0.10 & 1.99 & -0.77 & 2.52 & -1.89 & 86.5 & 12.2 & 1.4 \\
\hline $2-3$ & 20.7 & 3.16 & 22.8 & 0.09 & 1.91 & -1.00 & 2.59 & -2.22 & 68.9 & 31.1 & 0 \\
\hline $2-4$ & 23.0 & 3.49 & 22.3 & 0.14 & 1.76 & -0.82 & 2.49 & -2.45 & & & \\
\hline $2-5$ & 25.2 & 3.82 & 22.7 & 0.21 & & & & & 89.2 & 8.1 & 2.7 \\
\hline $2-7$ & 29.8 & 4.18 & 23.3 & 1.44 & 1.92 & -0.87 & 2.50 & -2.26 & & & \\
\hline $2-10$ & 36.6 & 4.27 & 24.0 & 1.11 & 2.09 & -0.88 & 2.47 & -1.86 & 82.4 & 12.2 & 5.4 \\
\hline $2-13$ & 43.8 & 4.37 & 24.1 & 1.37 & 1.98 & -0.90 & 2.48 & -2.33 & & & \\
\hline $2-16$ & 50.2 & 4.45 & 24.0 & 0.42 & 2.08 & -0.99 & 2.46 & -2.15 & & & \\
\hline $2-19$ & 57.0 & 4.54 & 23.5 & 1.89 & 2.29 & -0.68 & 2.55 & -2.18 & 73 & 24.3 & 2.7 \\
\hline $2-22$ & 63.8 & 4.63 & 23.7 & 1.14 & 2.23 & -1.03 & 2.47 & -2.18 & & & \\
\hline \multirow[t]{2}{*}{$2-25$} & 70.6 & 4.72 & 23.5 & 1.54 & 2.14 & -1.20 & 2.54 & -2.17 & 78.4 & 20.3 & 1.4 \\
\hline & 72.9 & 4.75 & & & 2.30 & -0.87 & & & & & \\
\hline $2-28$ & 77.4 & 4.81 & 24.1 & 1.24 & 2.03 & -0.86 & 2.46 & -2.43 & & & \\
\hline $2-31$ & 84.2 & 4.90 & 23.4 & 1.16 & & & 2.46 & -2.98 & 68.9 & 27 & 4.1 \\
\hline $2-32$ & 86.5 & 4.93 & 24.1 & 1.18 & 2.06 & -1.05 & & & & & \\
\hline $2-34$ & 91.1 & 4.99 & 23.3 & 1.01 & 2.05 & -1.05 & 2.52 & -2.40 & & & \\
\hline $2-36$ & 95.6 & 5.05 & 23.7 & 1.11 & 1.91 & -1.18 & & & 82.4 & 16.2 & 1.4 \\
\hline $2-37$ & 97.9 & 5.08 & 23.8 & 1.86 & 2.16 & -1.22 & & & & & \\
\hline $2-38$ & 100.1 & 5.11 & 24.2 & 0.80 & & & & & 81.1 & 16.2 & 2.7 \\
\hline $2-40$ & 104.7 & 5.17 & 23.5 & 1.12 & & & 2.49 & -2.50 & & & \\
\hline \multirow[t]{2}{*}{$2-42$} & 109.2 & 5.23 & 23.6 & 1.17 & & & & & & & \\
\hline & 111.5 & 5.26 & & & 1.99 & -1.55 & 2.53 & -2.96 & & & \\
\hline $3-1$ & 116.1 & 5.32 & 23.1 & 3.11 & 1.86 & -1.50 & 2.45 & -2.96 & 68.9 & 29.7 & 1.4 \\
\hline $3-5$ & 125.2 & 5.42 & & & 2.04 & -1.44 & 2.34 & -2.93 & & & \\
\hline $3-7$ & 129.8 & 5.47 & 23.0 & 3.18 & 1.55 & -1.35 & 2.58 & -2.48 & & & \\
\hline \multirow[t]{2}{*}{$3-11$} & 138.8 & 5.58 & 22.6 & 2.70 & 1.88 & -1.50 & 2.54 & -2.96 & & & \\
\hline & 147.9 & 5.68 & & & 1.76 & -1.95 & 2.36 & -3.40 & & & \\
\hline 3-19 & 157.0 & 5.78 & 22.7 & 2.22 & 1.99 & -1.67 & 2.40 & -3.47 & 54.1 & 45.9 & 0 \\
\hline $3-23$ & 166.1 & 5.89 & 22.6 & 2.99 & 1.77 & -1.84 & 2.43 & -3.54 & & & \\
\hline $3-25$ & 170.6 & 5.94 & 21.9 & 3.07 & 2.01 & -1.67 & 2.23 & -3.06 & & & \\
\hline $3-29$ & 179.7 & 6.04 & 23.9 & 4.98 & 2.12 & -1.69 & 2.19 & -3.28 & & & \\
\hline $3-32$ & 187.5 & 6.10 & 22.2 & 3.67 & & & 2.47 & -3.46 & 67.6 & 21.6 & 10.8 \\
\hline $3-35$ & 193.3 & 6.15 & 23.0 & 3.75 & & & 2.60 & -3.26 & & & \\
\hline 3-39 & 202.4 & 6.22 & 23.7 & 1.50 & 2.21 & -1.97 & 2.44 & -3.68 & & & \\
\hline
\end{tabular}


Table 2 Sampled core depths; ages; sea surface temperatures (SST); fluxes of C37 benthic foraminifera; relative abundance of pollens including Castanea, Abies, and Picea; and relative abundance of coccoliths (Continued)

\begin{tabular}{|c|c|c|c|c|c|c|c|c|c|c|c|}
\hline \multirow{2}{*}{$\begin{array}{l}\text { Sample } \\
\text { no. }\end{array}$} & \multirow{2}{*}{$\begin{array}{l}\text { Depth } \\
\text { (cm) }\end{array}$} & \multirow{2}{*}{$\begin{array}{l}\text { Age } \\
\text { (cal. } \\
\text { yrs } \\
\text { BP) }\end{array}$} & \multirow{2}{*}{$\begin{array}{l}\mathrm{C}_{37} \\
\text { alkenone } \\
\mathrm{SST}\left({ }^{\circ} \mathrm{C}\right)\end{array}$} & \multirow{2}{*}{$\begin{array}{l}\mathrm{C}_{37} \\
\text { alkenone } \\
\text { flux ( } \mu \mathrm{g} \\
\mathrm{cm}^{-2} \\
\left.\mathrm{kyr}^{-1}\right)\end{array}$} & \multicolumn{2}{|c|}{ N. labradorica } & \multicolumn{2}{|l|}{ N. Stella } & \multirow{2}{*}{$\begin{array}{l}\text { Gephyrocap } \\
\text { oceanica } \\
(\%)\end{array}$} & \multirow{2}{*}{$\begin{array}{l}\text { Emiliania } \\
\text { huxleyi } \\
(\% 0)\end{array}$} & \multirow{2}{*}{$\begin{array}{l}\text { The other } \\
\text { coccoliths } \\
(\% 0)\end{array}$} \\
\hline & & & & & $\delta^{18} \mathrm{O}(\%)$ & $\delta^{13} \mathrm{C}(\%)$ & $\overline{\delta^{18} \mathrm{O}(\%)}$ & $\delta \delta^{13} \mathrm{C}(\%)$ & & & \\
\hline $3-43$ & 211.5 & 6.29 & 22.0 & 5.02 & 1.83 & -2.82 & & & & & \\
\hline $4-1$ & 216.6 & 6.33 & 23.9 & 1.37 & & & 2.47 & -4.94 & 70.3 & 23 & 6.8 \\
\hline $4-5$ & 225.8 & 6.41 & 23.4 & 2.84 & & & & & & & \\
\hline $4-7$ & 230.8 & 6.45 & & & 2.13 & -1.75 & 2.52 & -3.93 & & & \\
\hline $4-11$ & 239.4 & 6.52 & 23.1 & 3.23 & & & 2.52 & -2.97 & & & \\
\hline $4-14$ & 246.3 & 6.57 & & & 2.35 & -2.32 & 2.47 & -3.80 & & & \\
\hline 4-17 & 253.1 & 6.64 & 23.8 & 1.61 & & & 2.48 & -3.33 & 73 & 24.3 & 2.7 \\
\hline $4-20$ & 260.0 & 6.71 & 23.3 & 1.08 & & & 2.60 & -2.95 & & & \\
\hline $4-24$ & 269.1 & 6.81 & 23.9 & 0.79 & 2.02 & -1.94 & 2.59 & -3.43 & & & \\
\hline $4-27$ & 275.9 & 6.89 & & & & & 2.74 & -3.45 & & & \\
\hline $4-30$ & 282.8 & 6.96 & 24.0 & 1.05 & 1.90 & -1.77 & 2.53 & -2.76 & & & \\
\hline $4-35$ & 294.2 & 7.09 & 22.7 & 1.72 & & & 2.61 & -3.55 & 55.4 & 39.2 & 5.4 \\
\hline $4-38$ & 301.0 & 7.16 & 23.0 & 0.66 & & & & & 47.3 & 48 & 4.7 \\
\hline $4-41$ & 307.8 & 7.24 & & & & & 2.67 & -4.49 & & & \\
\hline $5-2$ & 319.9 & 7.37 & 23.1 & 0.76 & & & 2.78 & -3.53 & & & \\
\hline $5-4$ & 324.5 & 7.42 & & & & & & & & & \\
\hline $5-8$ & 333.5 & 7.52 & 22.8 & 0.73 & & & 2.87 & -3.58 & 70.3 & 25.7 & 4.1 \\
\hline $5-15$ & 349.4 & 7.69 & 22.4 & 0.58 & & & 2.67 & -3.86 & & & \\
\hline 5-19 & 358.5 & 7.79 & & & & & 2.87 & -4.45 & & & \\
\hline $5-21$ & 363.0 & 7.84 & 23.0 & 0.52 & & & 2.86 & -4.24 & & & \\
\hline $5-25$ & 372.1 & 7.94 & 24.2 & 0.52 & & & 2.64 & -3.72 & 71.6 & 21.6 & 6.8 \\
\hline $5-27$ & 376.7 & 7.99 & 23.6 & 0.54 & & & 2.79 & -3.88 & & & \\
\hline
\end{tabular}

Original data of Alkenone SST and pollen are from Kawahata et al. (2009b)

Jōmon sites existed (Fig. 2b) (JOMON JAPAN; https:// jomon-japan.jp/en/).

Mutsu Bay showed a millennial cycle of alkenone SST fluctuation with warm periods during 7.0-5.9 cal. kyr BP (av. 23.4 ${ }^{\circ} \mathrm{C}$ ) and 5.1-4.1 cal. kyr BP (av. 23.8 ${ }^{\circ} \mathrm{C}$ ) and cold periods during $5.9-5.1 \mathrm{cal}$. kyr BP (av. $22.9^{\circ} \mathrm{C}$ ) and 4.12.3 cal. kyr BP $\left(22.7^{\circ} \mathrm{C}\right)$ (Kawahata et al. 2009b) (Fig. 2a; Table 2). The mean VF1 value was enhanced in 7.7-7.1 and 5.9-5.3 cal. kyr BP and reduced in 6.7-6.1 and 4.9$4.1 \mathrm{cal}$. kyr BP (Fig. 2e). In spite of some discrepancy around 5.1-4.9 cal. kyr BP, the general pattern of SST was fundamentally found to coincide with patterns in the assemblage of Ostracoda, successful zooplankton that live mainly in cool-temperate to subarctic surface water in the northwestern Pacific (e.g., Ozawa et al. 2004; Zenina 2009) (Fig. 2e). Q-mode factor analysis using an ostracod proportion matrix determined that the first factor (VF1) accounts for $59.7 \%$ of the total variance and was characterized by highly positive factor scores of cryophilic bay species, such as Yezocythere hayashii
(Irizuki et al. 2015). This species inhabits the Great Bay in Russia, at water depths of $13.5-72.5 \mathrm{~m}$ and water temperatures of $1.71-17.85^{\circ} \mathrm{C}$ (Schornikov and Zenina 2014). It lives where summer water temperatures are < $22^{\circ} \mathrm{C}$ and winter water temperatures are $<7^{\circ} \mathrm{C}$ (Ozawa et al. 2004); therefore, the VF1 tends to decrease as the SST increases (Irizuki et al. 2015). The profile (Fig. 2b) was strikingly similar to that of alkenone SSTs in Funka Bay, showing maxima around 6.5 and $4.5 \mathrm{cal}$. kyr BP and minima around 5.8 and $4.0 \mathrm{cal}$. kyr BP. Both graphs appear to be parallel if the reason for the difference of SST is attributable to latitude by $1^{\circ} 30^{\prime}$.

The SST fluctuation was also consistent with the relative abundances of coccolith species. Although alkenones in the ocean are derived mainly from the prymnesiophyte coccolithophorids Emiliania huxleyi and Gephyrocapsa oceanica, E. huxleyi can tolerate lower temperatures than G. oceanica (Mclntyre and Be 1967), and thus, the growth rate of E. huxleyi below $20^{\circ} \mathrm{C}$ is higher than that of $G$. oceanica (Rhodes et al. 1995). Consequently, E. huxleyi is 
dominant in the northern North Pacific (Harada et al. 2012). The relative abundance of G. oceanica, a major coccolithophore in this core, showed broad maxima at 6.7-6.3 and 5.2-3.9 cal. kyr BP, when E. huxleyi showed minimum abundances (Fig. 2d).

Aomori City provides hourly vertical SST, salinity, and other marine data using an automated monitoring system at east bay buoy site $\left(41^{\circ} 5^{\prime} \mathrm{N}, 140^{\circ} 59^{\prime} \mathrm{E}\right)$ (Aomori fishery research institute, http://www.aomori-itc.or.jp/ uminavi/), where SST shows a very high correlation with AT in the semi-enclosed Mutsu Bay in March to August. Therefore, the combined lines of evidence stated above generally suggest that the reconstructed SSTs (ATs) in early-midsummer peaked at around 6.5 and $4.8-4.3 \mathrm{cal}$. kyr BP and that the environments were cooler at 7.0, 5.9, and $4.1 \mathrm{cal}$. kyr BP in the Jomon sites surrounding the Tsugaru Strait (Fig. 2a).

\section{Annual temperature in Mutsu Bay}

The $\delta^{18} \mathrm{O}$ values measured in $N$. labradorica ranged from 2.61 to $5.61 \%$, averaging $3.88 \%$ o (Fig. 2f, Table 2). The values fluctuated over the last $7.0 \mathrm{kyr}$. Highresolution analysis between 7.0 and $4.0 \mathrm{cal}$. kyr BP found maxima at 6.41-5.90 cal. kyr BP and 4.89-4.41 cal. kyr $\mathrm{BP}$ and a minimum at $5.85-4.95 \mathrm{cal}$. kyr BP. However, $N$. stella $\delta^{18} \mathrm{O}$ values were $2.19-2.74 \%$ and average $2.50 \%$ (Fig. 2f). This value gradually decreased from 7.0 to $6.0 \mathrm{cal}$. kyr BP, with a small maximum during 6.0$5.35 \mathrm{cal}$. kyr BP. After $4.79 \mathrm{kyr}$ BP, the value remained constant.

Oxygen isotope values of benthic foraminiferal calcite provide a quantitative temperature estimate. The oxygen isotope value of biogenic carbonate is mainly controlled by temperature $\left(\mathrm{T},{ }^{\circ} \mathrm{C}\right)$ and the oxygen isotope composition (\%o) of seawater (O’Neil et al. 1969) as follows:

$$
T=16.9-4.38(\delta \mathrm{c}-\delta \mathrm{w})+0.1(\delta \mathrm{c}-\delta \mathrm{w})^{2}
$$

where $\delta \mathrm{c}$ and $\delta \mathrm{w}$ represent the $\delta^{18} \mathrm{O}$ of calcite and seawater, respectively. The water mass in the Tsugaru Strait in the mid-Holocene after $6.2 \mathrm{cal}$. kyr BP has been controlled by one branch of the Tsushima Current, and the salinity- $\delta^{18} \mathrm{O}$ relationship of water has been reported from seawater samples (Kim et al. 2005). This relationship is as follows:

$$
\delta^{18} \mathrm{O}_{\mathrm{sa}}=0.24 \times \text { Salinity }-8.13
$$

where $\delta^{18} \mathrm{O}_{\mathrm{sa}}$ is the $\delta^{18} \mathrm{O}$ of each water sample. Currently, the Tsushima Current of the Tsugaru Peninsula has a salinity of approximately $34.5-34.7$ in the summer (Ogawa 1974; however, Mutsu Bay has higher salinity water near the seafloor (Otani and Terao 1973). The $\delta^{18} \mathrm{O}$ values of seawater are generally linked to the hydrological cycle and are, thus, a function of evaporation, atmospheric vapor transport and return of freshwater to the ocean via precipitation, runoff, or melting icebergs (Horikawa et al. 2015). However, the water mass in Mutsu Bay is more dependent on the Tsugaru Current. According to the marine dataset recorded by the automated monitoring system in Mutsu Bay, its salinity is approximately 33.8 (Aomori fishery research institute; http:// www.mutsuwanbuoy.jp/timeseries/), which converts to a $\delta^{18} \mathrm{O}$ value of $-0.018 \%$. This value is comparable to the observed value $(+0.2 \%)$ of the Tsushima Current (Oba et al. 1991) and is higher than that $(-1.0 \%)$ of the Oyashio Current (Chinzei et al. 1987). The conversion factor from the Vienna Standard Mean Ocean Water (V-SMOW) to the Vienna Standard Pee Dee Belemnite (V-PDB) scale was performed according to Bemis et al. (1998):

$$
\begin{aligned}
\delta^{18} \mathrm{O}(\mathrm{V}-\mathrm{PDB})= & 0.9998 \\
& \times \delta^{18} \mathrm{O}(\mathrm{V}-\mathrm{SMOW})-0.2[\% \mathrm{o}] .
\end{aligned}
$$

The benthic foraminifera $N$. labradorica have had calcification temperatures of $7.8^{\circ} \mathrm{C}$ for the last $1 \mathrm{kyr}$, which is comparable to the annual bottom water temperature of $7.5^{\circ} \mathrm{C}$ at $61 \mathrm{~m}$ estimated from the extrapolation from water temperatures at $30 \mathrm{~m}\left(11.5^{\circ} \mathrm{C}\right)$ and $40 \mathrm{~m}\left(10.2^{\circ} \mathrm{C}\right)$ depth at at east bay buoy site (Fig. 2f). Both dwell on the seafloor in the northern North Pacific, Japan Sea, and Sea of Okhotsk (Inoue 1980). N. labradorica consistently exhibits subsurface maxima between 1.0 and $2.0 \mathrm{~cm}$, whereas $N$. stella is widely distributed on the continental shelf and thrives in the deeper subsurface and/or more oxygen-depleted $(<2 \mu \mathrm{M})$ sediments of the Santa Barbara Basin (Alve and Bernhard 1995). This difference is supported by the lower $\delta^{13} \mathrm{C}$ values obtained for $N$. stella relative to those of $N$. labradorica (Fig. $2 \mathrm{~g}$ ). Therefore, the $\delta^{18} \mathrm{O}_{\mathrm{sa}}$ of $N$. labradorica and $N$. stella can be taken to represent the annual mean temperature of bottom water and the relevant subsurface sediments, respectively (Fig. 2f). Whereas temperatures in the subsurface sediments were constant over the last $7 \mathrm{kyr}$, the annual mean temperature of bottom water was estimated to have been highest at $6.0 \mathrm{cal}$. yr BP before, decreasing at $4.5 \mathrm{cal}$. yr BP by several degrees (Fig. 2f). This cooling trend was semi-quantitatively correlated with alkenone flux, which is generally controlled by SST and the supply rate of nutrients. According to sediment trap experiments, alkenone production almost stopped during cold winter-spring seasons in this area (Kawahata et al. 2009a). Probably, annual-based warmer environments were expected to enhance alkenone flux at $6.4-5.2 \mathrm{cal}$. kyr BP (Fig. 2j).

Castanea is an important taxon of warm-temperature deciduous trees (e.g., Kitagawa and Yasuda 2004). In contrast, Picea and Abies, which are widespread in 
northern temperate and boreal climates, are proxies for a relatively cold subarctic climate (Fig. $2 \mathrm{~h}$ ). Both were negatively correlated with Castanea $(r=0.60$ and 0.48 , respectively) (Table 2 ) and showed that the climate was warmer at 5.9-4.2 cal. kyr BP, then suddenly cooled down. Accordingly, the period at 6.0-5.0 cal. kyr BP might show annual-based warmer environments than expected from alkenone SST in early-midsummer. Overall, both proxy groups propose that the Jomon people living at the Sannai-Maruyama site would generally have enjoyed a warmer climate that led to improved living conditions between Bond events 4 and 3 .

\section{Temperature change in relation to the intensity of the} Asian Summer Monsoon during the mid-Holocene

Fluctuation of the intensity of the Asian Summer Monsoon can be evaluated around Bond events 4 and 3. At first glance, a broad maximum in SSTs (ATs) around 5.0-4.2 cal. kyr BP, the Mid-Holocene Hypsithermal environment, can be clearly associated with a slightly increase in sunspot numbers although the summer (winter) daily insolation gradually declined (increased) during the last $8 \mathrm{kyr}$ (Fig. 3a, f, g). Sunspot numbers estimated from variations in tree ring $\Delta^{14} \mathrm{C}$ variation generally provide a good proxy for solar output variations (Fig. 3f). When sunspot numbers increase, the solar output increases (Usoskin et al. 2007). However, it is well known that solar radiation alone is too small to explain the amplitude of environmental fluctuation seen during this period. Additional factors such as the El Niño Southern Oscillation and/or the Asian Monsoon are required to amplify the effects and/or to trigger globally significant climatic change (e.g., Emile-Geay et al. 2007; Beaufort and Grelaud 2017; Clift 2017).

Considering short-term variations, two SST minima at 5.9 and 4.2 cal. kyr BP roughly correspond to early Bond event 4 and late Bond event 3, respectively, resulting from the North Atlantic cooling episodes identified from ice-rafted debris (Fig. 2c) (Bond et al. 1997). The forcing mechanisms are, however, less obvious than those at 8.2 ka BP (Bond event 5), when massive volumes of freshwater were released into the North Atlantic (Fig. 2c) (Alley and Ágústsdóttirab 2005). There are no systematic correlations with average summer and winter insolation, volcanic aerosols, or increases in atmospheric $\mathrm{CO}_{2}$. It is suggested that southward migration of the Intertropical Convergence Zone might account for the low latitude aridity during Bond events (Mayewski et al. 2004) and that this would be in correlation with the increase in strength of the westerlies over the North Atlantic, enhanced precipitation, and consequent glacier advance in western North America, resulting in a $1-2^{\circ} \mathrm{C}$ cooling of the North Atlantic surface waters (Bond et al. 1997). At present, this event inhibits and weakens the Asian Monsoon (e.g., Tada and Murray 2016).

In contrast, an increased EASM could create heat energy and moisture from lower to middle latitudes in Far East Asia and the western Pacific (Qui et al. 2017). According to a simulation study, the EASM was significantly enhanced during the middle Holocene and characterized by increased southerly winds in eastern China, resulting in more rainfall in northern China with slight reductions in rainfall in southern China (Liu et al. 2014). The analysis of the relative latitudinal shift of the westerly jet from the electron spin resonance (ESR) signal of eolian dust from Chinese deserts showed large southward shifts around 6.1 and 5.1 cal. kyr BP and in 4.5-4.0 cal. kyr BP especially between Bond events 4 and 3, resulting in a southward migration of the EASM rainband (Fig. 3h) (Nagashima et al. 2013). In this condition, the mid to higher latitude in Far East Asia could experience cool arid climates (e.g., Tada et al. 2016). The result is consistent with the reduction of the EASM to around 6.1, 4.7, and $4.2 \mathrm{cal}$. kyr BP (Bond events 4 and 3), as deduced from $\delta^{18} \mathrm{O}$ records of stalagmites in Dongge cave (Fig. 3i) (Wang et al. 2005).

There were periods of drought between 6.2 and $5.9 \mathrm{cal}$. yr BP along the middle and lower reaches of the Yangtze in China (Wang and Huang 2006; Wang et al. 2014). The environmental record from Qinghai Lake indicated that a relatively stable, warm, and humid climate at 5.83-4.90 cal. kyr BP provided conditions conducive to the development of the late Neolithic Majiayao Culture near the upper Yellow River in China. This period had the warmest temperatures and highest precipitation during the Holocene (Liu et al. 2010, 2014). Drought developed at $4.9-4.7 \mathrm{cal}$. kyr BP and may have moved eastward, continuing until around $4.0 \mathrm{cal}$. kyr BP. This is consistent with the EASM estimated from the inner shelf of the East China Sea (Wang et al. 2014). Therefore, a broad northward shift of the westerly jet, in association with strengthened EASM, could have fostered a relatively warm climate at 6.0-4.2 cal. kyr BP, when the Sannai-Maruyama site flourished. Further investigation is needed to conduct the quantitative reconstruction of the environmental parameters and evaluate the climatic and/or environmental influences on human activity.

\section{Prosperity of the Sannai-Maruyama site by high production density by hansaibai of Castanea trees} Hansaibai of Castanea and Aesculus trees has been suggested as a strategy for food production near many Jōmon archeological site settlements in northernmost Honshu, Japan (e.g., Nakao 1976). This is supported by the analysis of pollen assemblage, nut sizes and DNA of Castanea, and land use at the Sannai-Maruyama site (e.g., Tsuji 2001; Sato and Ishikawa 2004). Archeologically, ecological works 
emphasize the impacts of human activities on their surrounding environment. This is particularly relevant in the context of Jomon archeology because the Jomon people were clearly engaged in a significant level of environmental management (Habu and Hall 2013). Actually, Jōmon people could grow trees rather easily (Nishida 1981; Yokoi 1989). Based upon pollen studies, Castanea contributed more than $70 \%$ of the total pollen at Sannai-Maruyama site from 5.05 to $4.10 \mathrm{cal}$. kyr BP during warmer periods, in contrast to that of less than $5 \%$ in core PC-02 (Yoshikawa et al. 2006; Kawahata et al. 2009b). Aesculus tree tended to be more common along the valleys during relatively cold periods, contributing 30\% of the total pollen (Kitagawa and Yasuda 2004, 2008). Castanea also served as an important building material. Six pillars approximately $1 \mathrm{~m}$ in diameter support a large structure built at $4.6 \mathrm{cal}$. kyr BP (Sannai Maruyama special historical site; http://sannaimaruyama.pref.aomori. jp/english/). Northernmost Honshu, Japan, is near the northern limit of the Castanea distribution in Japan (Kitagawa and Yasuda 2004). Currently, its northern limit of the commercial production is approximately $38^{\circ} \mathrm{N}$ (Shiosawa 1988). Therefore, the Sannai-Maruyama location is outside the present geographical range of Castanea. This demonstrates that from agricultural point of view, AT would have been a critical factor for people living in this area.

Food availability is a crucial factor for the evaluation of human activity from the basis of its production rate and density. Also it is hypothesized that the increase and decrease in settlement size at Sannai-Maruyama were correlated with the development and decline of subsistence intensification, respectively, with a focus on a particular type of plant food (Habu and Hall 2013). The community at the Sannnai-Maruyama site utilized food resources such as nuts, fish, and a wide diversity of plants. Niimi (1999) tried to conduct the first-grade approximation estimates of population by assuming that chestnuts are produced over $20 \mathrm{~km}^{2}$ at a density of 0.01 chestnut tree $/ \mathrm{m}^{2}$ and that $80 \%$ of calories are supplied from chestnut trees within $10 \mathrm{~km}$ walking distance of the site, from which it was suggested that approximately 2000 people might have survived in $200 \mathrm{~km}^{2}$ of the area. This kind of the work provides a valuable image of Jomon people, but the estimate might, however, be too high because a population density of 10 persons $/ \mathrm{km}^{2}$ is almost 10 times the estimated round number in a hunter-fisher-gatherer society. Other estimates suggest 1-2 person $/ \mathrm{km}^{2}$ as a maximum, constrained by food requirement in the Jomon society (Kito 2000).

Seafood would also have been a major food source in northern Japan during the early Jomon period due to poor vegetation in the cold climate (Kawahata et al. 2017b). This is supported by evidence that Jomon pottery was predominantly used for cooking marine and freshwater resources (Lucquin et al. 2016). Salmon and sole were particularly important protein sources for Jomon people because the former could be caught easily during its annual upstream swim. Since the mean size of salmon $(3 \mathrm{~kg})$ provides $2800 \mathrm{kcal}, 260$ salmon are required for annual required calories per person $\left(7.3 \times 10^{5}\right.$ $\mathrm{k}$ calories). In order to provide the required calories for 6 persons, 5 salmon, soles, or equivalent fish must be caught daily. Coastal fishing sites associated with Jōmon settlements were generally small scale.

Chestnut is a high-calorie fruit $(1.8 \mathrm{kcal} / \mathrm{g})$ and is further enriched in protein; vitamins $\mathrm{A}, \mathrm{B} 1, \mathrm{~B} 2$, and $\mathrm{C}$; and potassium. If 1 Jōmon person required $2000 \mathrm{kcal} /$ day, a total of $7.3 \times 10^{5} \mathrm{kcal} /$ year corresponded to $4.05 \times 10^{5} \mathrm{~g} /$ year of chestnuts. If 1 chestnut tree produces $4000 \mathrm{~g}$ of chestnuts, including $2800 \mathrm{~g}$ of edible part, it corresponds to $5040 \mathrm{kcal}$. At a production of $80 \mathrm{~g}(100.8 \mathrm{kcal})$ of chestnut $/ \mathrm{m}^{2}, 0.0072 \mathrm{~km}^{2}$ could be required to support 1 person for 1 year (Fig. 4a). If the rate was almost half of the modern production rate at that time, $0.015 \mathrm{~km}^{2}$ should be required. This value is nearly 60 times higher than that $\left(1 \mathrm{~km}^{2}\right)$ required per person in the hunterfisher-gatherer community (Fig. 4a). Paddy rice farming near permanent places of residence and metalworking advance were characteristic of the Yayoi Period (2.9-1.6 cal. kyr BP), a Japanese prehistoric period that immediately followed the Jömon period (Sato 2001; Kono 2006). Since the calorie content of unpolished rice is $1.65 \mathrm{kcal} /$ $\mathrm{g}$ and the Yayoi people could produce $180 \mathrm{~g}$ ( $297 \mathrm{kcal}) /$ $\mathrm{m}^{2}$ at the Toro site (Fig. 1a), central Japan, almost one third of its production at present, $0.0025 \mathrm{~km}^{2}$ could be required to support 1 person per year (Video travel guide of Japan; http://www.mustlovejapan.com/subject/ toro_archaeological_site/) (Fig. 4c). These estimates suggest that hansaibai of Castanea should have provided a sufficiently high production density-one sixths of the rice production rate, but enough to settle at a single place-and that a maximum of 90 persons might be supported only by chestnut at the Sannnai-Maruya site, including the surrounding area $\left(1 \mathrm{~km}^{2}\right)$. Pollen analysis in this study shows that Castanea constitutes only $5 \%$ of the total grains of pollen in core PC-02 (Fig. 2h). If this value is applied to the central part of the Aomori Plane $\left(100 \mathrm{~km}^{2}\right)$ at the same density, approximately 300 people could be supported. Although these estimates have appreciable error for the estimation, because horse chestnuts and wild game were also important additional food, the function of hansaibai should be the subject of future evaluation.

Although the Gini-Simpson index showed little change in the assemblage of pollen around Bond events 4-3, a warm climate could have promoted increased growth of Castanea whereas, during colder periods, Castanea may 


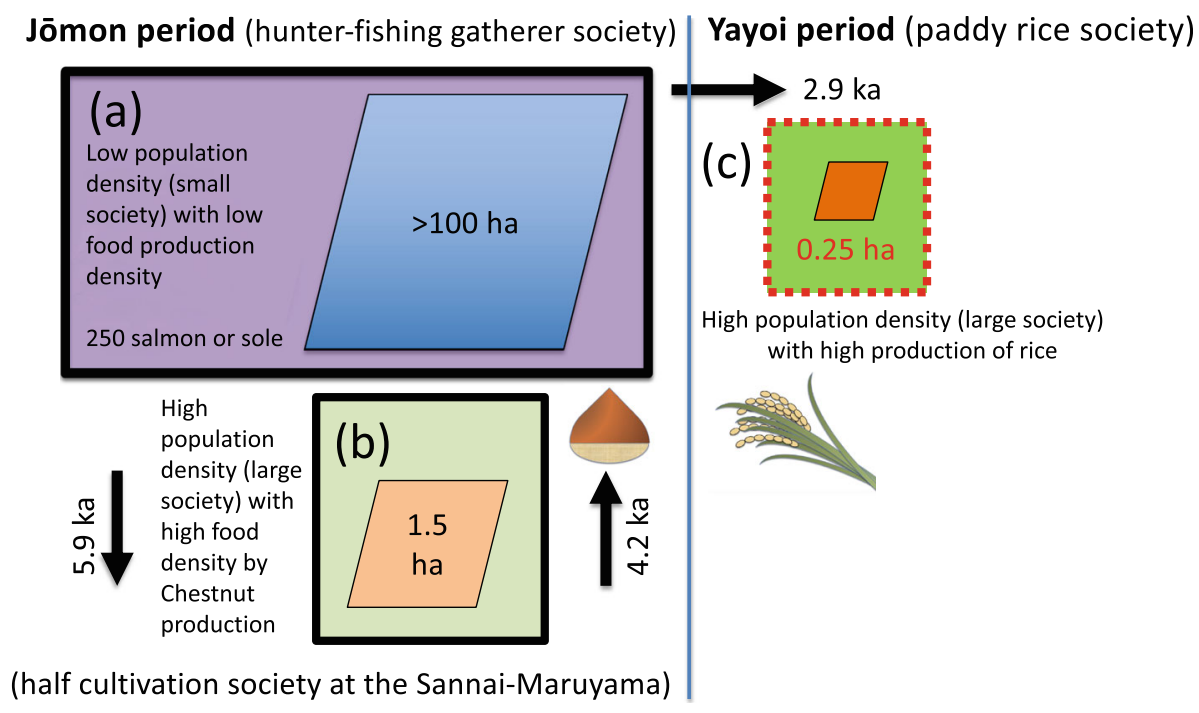

Fig. 4 Schematic diagram showing the area required for total calories $\left(7.3 \times 10^{5} \mathrm{kcal} /\right.$ year $)$ to support one person per year. a Hunter-fishergatherer societies in the Jōmon era generally required larger areas (more than $100 \mathrm{ha}\left(1 \mathrm{~km}^{2}\right)$ ) due to low production density. In contrast, $\mathbf{b}$ chestnut production by hansaibai could require only 1.5 ha due to high production density in Jōmon era. This value is only sixth times that $(0.25$ ha) required by rice production in the Yayoi era $(\mathbf{c})$. Thick black of outer frame lines represent the Jōmon society while the red dotted lines represent the Yayoi society. Green squares represent high production density $(\mathbf{b}, \mathbf{c})$ while purple squares show low production density (a). In general, Jōmon societies were characterized by low population density due to low food production density. In contrast, high production density of chestnut by hansaibai influenced by warm climate allowed the settlement of the Sannnai-Maruya site at 5.9 cal. kyr BP (b) while cool climate would have eventually collapsed the site at $4.2 \mathrm{cal}$. kyr BP, resulting in the dispersal of the population to smaller communities (a). Paddy ricebased societies in association with villages started at 2.9 cal. kyr BP in western Japan (c)

have failed to reproduce and become susceptible to disease (Fig. 2h, i) (Shiosawa 1988). Although Aesculus turbinate is able to survive at cooler climate than Casta$n e a$, it typically grows in the lowland, along small rivers (personal communication with Ms. Ito). Therefore, if Castanea-dominated forests declined, the Jōmon people might have found it challenging to settle at a single place, as distances to collect food increased (Fig. 4b). Instead, it would have been more efficient to live scattered over the Aomori Plain, according to the low density of the food production due to cooler climate (Fig. 4a). This suggestion is consistent with the hypothesis that a decrease in subsistence and food diversity, which was a result of subsistence specialization, made the SannaiMaruyama economic system more vulnerable to minor changes in other variables (Habu and Hall 2013). Although other food sources and the quantitative efficiency of hansaibai strategies have not been considered, these estimates nonetheless provide a framework within which to understand the correlation of population density with Castanea-dominated forests together with hansaibai in the Sannai-Maruyama site (Fig. 4b).

\section{Dispersion of people at the Sannai-Maruyama site across late Bond event 3}

The prehistory of populations in the Japanese archipelago has only recently been reconstructed. Sekine (2014) compiled an archeological site map with the number of ruins and pit dwellings provided by Aomori Prefecture and analyzed the number of archeological sites and population versus their age (Fig. 3c). Despite a dramatic decline of AT, the number of archeological sites increased in the Aomori Prefecture as a result of dispersion to small villages. Interestingly, it is highly possible that the population never significantly changed from the last stage of the middle Jōmon to the late stage of the late Jōmon, based on estimates of the total floor space of the pit dwellings excavated. The result is generally consistent with other estimates of population changes in Aomori (Crèma et al. 2016) (Fig. 3b). In general, Jōmon societies were characterized by low population densities due to low food production densities. However, a high production density of chestnuts by hansaibai, influenced by the warm climate, allowed the settlement of the largest Jōmon society at the Sannnai-Maruya site at around $5.9 \mathrm{ka}$ (Fig. 4b). Later, cool climates would result in the collapse of the site, resulting in the dispersal of people to smaller communities in the surrounding area (Fig. 4a).

A haplotype is, in the simplest terms, a specific group of genes that a progeny inherits from one parent. Analyses of the Jomon skeletons in Hokkaido showed that mitochondrial DNA haplogroups N9b, D4h2, G1b, and M7a were observed in individual samples, with N9b being predominant (Adachi et al. 2011; Takigawa 2012). 
The fact that all these haplogroups, except M7a, were observed with relatively high frequency in the southeastern Siberians, but were absent in Southeastern Asian populations, implies that most of the Hokkaido Jomon people could be direct descendants of Paleolithic Siberians. This is consistent with the N9b constituting about $60 \%$ of the Jomon skeletons of the Tohoku $(N=20)$ (Adachi 2012; Takigawa 2012). Another Jōmon marker is haplogroup M7a, which might, however, originate from Southeast Asia (Shinoda 2015).

Recently, ancestral population dynamics can also be estimated based on modern Japanese molecular sequences (Peng and Zhang 2011). By examining the profile of different mitochondrial DNA haplogroups, one finds different profiles. Haplogroups N9b and M7a show the progressive population growth shortly after the start of Jomon to the present (Fig. 3d). This could be attributed to some successful adaptive subsistence strategies well suited to changing Jōmon environments. Around $10-15 \%$ of the mitochondrial DNA pool in the current Japanese population originated from that of the Jomon people (Fig. 3d).

In contract to the Jomon's haplogroups, the remaining accounts for $90-85 \%$ of modern Japanese. Most of them are descendant from the immigrants from Far East Asia after $2.9 \mathrm{cal}$. kyr BP, who had stayed considerably in China. Time series of the relative population size of total Japanese people (solid line) by Saito (2017) showed a broad minimum around $4.0 \mathrm{cal}$. kyr BP, which is consistent with those of haplogroups D4, B4, B5, and F, accounting more than half of modern Japanese (Peng and Zhang 2011) (Fig. 3d). Recently, Kajita et al. (2018) reported that extraordinarily severe abrupt cold episodes (i.e., $3-4{ }^{\circ} \mathrm{C}$ drop in SST) occurred frequently in the Yangtze delta region around 4.4-3.8 cal. kyr BP (Fig. 3e). The cold climatic event started about $0.2 \mathrm{kyr}$ earlier than at the Sannai-Maruyama site, northern Japan. Hundreds of sites of Neolithic cultures have been found in the Yangtze delta region in 7.5-4.2 cal. kyr BP (Stanley et al. 1999; Chen et al. 2005; Zhang et al. 2005; Itzstein-Davey et al. 2007a, b). Especially, the Songze (5.9-5.2 cal. kyr BP) was followed by the Liangzhu (5.2-4.2 cal. kyr BP), which showed well technological and social development. Artifacts from the Liangzhu occupation have provided evidence of advanced rice cultivation. It is well known that the Liangzhu terminated mysteriously around $4.2 \mathrm{cal}$. kyr BP. Currently, the reason behind the time lag by $0.2 \mathrm{kyr}$ between the first sudden drops of SST and the disappearance of the culture remains unclear. However, one possibility is that some of people might overcome a lot of obstacles by the first deteriorated climate but could be overwhelmed by extreme cold environments several times. In the Bronze Age, Maqiao culture (3.9-3.2 cal. kyr BP) appeared after a period of about 300 years without a trace of human settlement (the so-called cultural interruption). Archeological evidence showed that the number of Neolithic cultural sites and population dramatically decreased during this period (Chen et al. 2005). In addition, the Maqiao culture might have originated from different groups from the Liangzhu people because of material less sophisticated than those of the Liangzhu (Stanley et al. 1999). The other Neolithic settlements located around the upper reaches of the Yangtze River were also abandoned (Yasuda et al. 2004). Anyway, probably, these cold episodes could bring sufficiently severe damage to rice cultivation, constituting a plausible explanation for the demise of the Yangtze Neolithic civilization by damaging population around the area. Afterward, the people living along the coast of East China Sea came to Japanese islands with paddy rice cultivation technology because Japanese paddy rice originated from China based upon its DNA analysis (Sakitani 2008; Sato 2009). On the other hand, people around the Sannnai-Maruyama site managed to survive across $4.2 \mathrm{ka}$ event in spite of extraordinary climate change. The contrast of these ancestral population dynamics between different groups in response to different climatic events suggests that the mitochondrial DNA haplogroups could be a good archive for paleoclimate and/or paleoenvironments. To better understand these processes, further investigation is required to reconstruct other climate parameters such as rainfall, aridity, and cloudiness to control food supply and human society quantitatively and to analyze mitochondrial DNA of Jōmon, Yayoi, and ancient Far East people.

\section{Conclusions}

The change in climate known as the $4.2 \mathrm{ka}$ event has received much attention and has been cited as a plausible explanation for the collapse of major ancient civilizations/ societies in Egypt, the Indus Valley, Mesopotamia, China, and Japan. The climatic/environmental fluctuation between Bond events 4 and 3 around the Sannai-Maruyama site (5.9-4.2 cal. kyr BP), the largest and well-studied midHolocene (mid-Jōmon) archeological site, was investigated. The contrast in response to different climatic events suggests that the mitochondrial DNA haplogroups could be a good archive for paleoclimate and/or paleoenvironments:

1) By using data for the stable isotopic compositions of benthic foraminifera and the relative abundance of coccoliths, as well as by re-evaluation of Ostracoda and pollen data and alkenone accumulation rate, overall, it is suggested that the Jōmon people living at the Sannai-Maruyama site would generally have enjoyed a warmer climate that led to improved living conditions between Bond events 4 and 3 . 
2) Hansaibai (selective preservation or growth) of Castanea could have supported high population density, resulting in large community at the SannaiMaruyama site. Cooling episode at $4.2 \mathrm{cal}$. kyr BP could have caused the decline of chestnut hansaibai, leading to the collapse of the site.

3) A broad northward shift of the westerly jet, in association with strengthened East Asian Summer Monsoon, could have fostered a relatively warm climate at 6.0-4.2 cal. kyr BP, when the SannaiMaruyama site flourished.

4) Recent archeological results suggested no large decline of the population but, instead, a dispersal to the surrounding area at $4.2 \mathrm{cal}$. kyr BP. It is consistent with ancestral population dynamics for the descendent from Jōmon people based on modern Japanese molecular sequences. In contrast, the immigrants from Far East Asia to the Japanese Archipelago with paddy rice cultivation technology after 2.9 cal. kyr BP experienced severe cold events in eastern China around $4.2 \mathrm{ka}$ event, which were confirmed by ancestral population dynamics. The contrast in response to different climatic events suggests that the mitochondrial DNA haplogroups could be a good archive for paleoclimate and/or paleoenvironments.

\section{Abbreviations}

AT: Atmospheric temperature; EASM: East Asian Summer Monsoon; INTIMATE: Integration of ice-core, marine and terrestrial records; Vienna Standard Mean Ocean Water; SST: Sea surface temperatures; TWC: Tsugaru Warm Current; V-PDB: Vienna Standard Pee Dee Belemnite

\section{Acknowledgements}

We thank a chief editor (Prof. J. Matsumoto) and two anonymous reviewers for their helpful and valuable suggestions on improving our manuscript. We are grateful to H. Yamamoto, K. Ohkushi (Kobe University), Dr. S. Sakata (National Institute of Advanced Industrial Science and Technology (AIST), Dr. K. Minoshima, (AIST), and Ms. N. Hokanishi (University of Tokyo) for the analysis of alkenones and stable isotopes of foraminifera. Mr. H. Kajita (University of Tokyo) who drew some figures and Miss A. Maeda (University of Tokyo) who calculated diversity are also acknowledged. We gratefully acknowledged Dr. J. Habu (University of California) on inviting us to her innovative workshops operated under RIHN program of "Long-term Sustainability through Place-Based, Small-Scale Economies: Approaches from Historical Ecology" and to have fruitful discussion. This research was partly supported by Grants-in-Aid from the Japan Society for the Promotion of Science to H.K. (nos. 1934014622224009 and 15H02139).

\section{Authors' contributions}

HK proposed and designed the study. He analyzed the samples and data by himself. The author read and approved the final manuscript.

\section{Authors' information}

No special information for HK

\section{Funding}

This work was supported by JSPS KAKENHI grant numbers 1934014622224009 and $15 \mathrm{H} 02139$

\section{Availability of data and materials}

Data and materials were collected by HK under his scientific funds. But if some would like to share HK's samples, please contact the author for data requests.

\section{Ethics approval and consent to participate}

There is no part on human participants, human data, or human tissue in this manuscript. Also, this manuscript does not report on or involve the use of any animal or human data or tissue.

\section{Consent for publication}

There is no other individual person's data in any form (including individual details, images, or videos). This manuscript does not contain any individual personal data.

\section{Competing interests}

The author declares that he has no competing interests.

Received: 3 September 2018 Accepted: 24 September 2019

Published online: 31 October 2019

\section{References}

Adachi N (2012) Investigation of a genotype of "Emishi" - the analysis of ancient people living in Tohoku area, northern Japan. Shimin-no-Kokogaku (Archaeology for citizens) 12:95-104 (in Japanese)

Adachi N, Shinoda K, Umetsu K, Kitano T, Matsumura H, Fujiyama R, Sawada J, Tanaka M (2011) Mitochondrial DNA analysis of Hokkaido Jomon skeletons: remnants of archaic maternal lineages at the southwestern edge of former Beringia. Am J Phys Anthropol 146:346-360. https://doi. org/10.1002/ajpa.21561

Alley RB, Ágústsdóttirab AM (2005) The 8k event: cause and consequences of a major Holocene abrupt climate change. Quaternary Sci Rev 24:1123-1149

Alve E, Bernhard JM (1995) Vertical migratory response of benthic foraminifera to controlled decreasing oxygen concentrations in an experimental mesocosm. Mar Ecol Prog Ser 116:137-151

Aomori Prefecture (2002) Aomoriken-shi, betsu-hen, Sannai-Maruyama-iseki (History of Aomori prefecture, added edition, Sannai-Maruyama site), pp 1501 (in Japanese)

Beaufort L, Grelaud M (2017) A 2700-year record of ENSO and PDO variability from the Californian margin based on coccolithophore assemblages and calcification. Prog Earth Planetary Sci 4:5. https://doi. org/10.1186/s40645-017-0123-z

Bemis B, Spero HJB, Lea D (1998) Reevaluation of the oxygen isotopic composition of planktonic foraminifera: experimental results and revised paleotemperature equations. Palaeogeogr Paleoclimatol Palaeoecol Paleoceanogr 13:150-160

Berger A (1978) Long-term variations of daily insolation and quaternary climatic changes. J Atmos Sci 35:2362-2367

Biraben JN (1993) Le Point sur l'Histoire de la Population du Japon. Population. 48:443-472

Biraben JN (2005) The history of the human population from the first beginnings to the present in "demography: analysis and synthesis: a treatise in population" (Eds: Graziella Caselli, Jacques Vallin, Guillaume J. Wunsch). Vol 3, Chapter 66: 5-18, Academic, San Diego

Bond G, Kromer B, Beer J, Muscheler R, Evans MN, Showers W, Hoffmann S, LottiBond R, Hajdas I, Bonani G (2001) Persistent solar influence on North Atlantic climate during the Holocene. Science 294:2130-2136

Bond G, Showers W, Cheseby M, Lotti-Bond R, Almasi P, deMenocal P, Priore P, Cullen HR, Hajdas I, Bonani G (1997) A pervasive millennial-scale cycle in North Atlantic Holocene and glacial climates. Science 278:1257-1266

Chandler T (1987) Four thousand years of urban growth: An historical census. St. David's University Press, New York, pp 1-656, ISBN 0-88946-207-0

Chen Z, Wang Z, Schneiderman J, Tao J, Cai Y (2005) Holocene climate fluctuations in the Yangtze delta of eastern China and the Neolithic response. The Holocene 15:915-924

Chinzei K, Fujioka K, Kitazato H, Koizumi I, Oba T, Oda M, Okada H, Sakai T, Tanimura Y (1987) Postglacial environmental change of the Pacific Ocean off the coasts of Central Japan. Mar Micropaleontol 11:273-291

Claussen M, Kubatzki C, Brovkin V et al (1999) Simulation of an abrupt change in Saharan vegetation in the mid-Holocene. Geophys Res Lett 26:2037-2040 
Clift PD (2017) Cenozoic sedimentary records of climate-tectonic coupling in the Western Himalaya. Prog Earth Planetary Sci 4:39. https://doi.org/10.1186/ s40645-017-0151-8

Crèma ER, Habu J, Kobayashi K, Madrella M (2016) Probability distribution of ${ }^{14} \mathrm{C}$ dates suggests regional divergences in the population dynamics of the Jomon Period in Eastern Japan. PLoS One 11:e0154809. https://doi.org/10. 1371/journal.pone.0154809

Cullen HM, deMenocal PB, Hemming S, Hemming G, Brown FH, Guilderson T, Sirocko F (2000) Climate change and the collapse of the Akkadian empire: evidence from the deep sea. Geology 28:379-382

deMenocal P (2001) Culture responses to climate change during the late Holocene. Science 292:667-673

Emile-Geay J, Cane MA, Seager R, Kaplan A, Almasi P (2007) El Nino as a mediator of the solar influence on climate. Paleoce Anography 22:PA3210. https://doi. org/10.1029/2006PA001304

Gasse F (2000) Hydrological changes in the African tropics since the Last Glacial Maximum. Quat Sci Rev 19:189-211

Gini C (1912) In: Pizetti E, Salvemini T (eds) Variabilit'a e mutabilit'a, Ristampato in Memorie di Metodologica Statistica, vol 1955. Liberia Eredi Virgilio Veschi, Roma

Habu J (2004) Ancient Jomon of Japan. Cambridge University Press, UK, pp $1-332$

Habu J (2008) A growth and decline in complex hunter-gatherer societies: a case study from the Jomon period Sannai Maruyama site, Japan. Antiqueity 82: 571-583

Habu J, Hall ME (2013) Climate change, human impacts on the landscape, and subsistence specialization: historical ecology and changes in Jomon huntergatherer lifeways. In: Thompson VD, Waggoner J (eds) The Historical Ecology of Small Scale Economies. University Press of Florida, Gainesville, pp 65-78

Harada N, Sato M, Oguri K, Hagino K, Okazaki Y, Katsuki K, Tsuji Y, Shin KH, Tadai O, Saitoh S, Narita H, Konno S, Jordan RW, Shiraiwa Y, Grebmeier J (2012) Recent environmental changes enhance coccolithophorid blooms in the Bering Sea. Glob Biogeochem Cycles 26:GB2036. https://doi.org/10.1029/ $2011 \mathrm{~GB} 004177$

Horikawa K, Kodaira T, Zhang J, Murayama M (2015) $\delta^{18}$ Osw estimate for Globigerinoides ruber from core-top sediments in the East China Sea. Prog Earth Planetary Sci 2:19. https://doi.org/10.1186/s40645-015-0048-3

Inoue $Y$ (1980) Distribution of recent benthic foraminifera in the adjacent seas of Japan. Part 2, special report technical laboratory. Japan Petrol Explor 307:41-41

Irino T, Tada R, Ikehara K, Sagawa T, Karasuda A, Kurokawa S, Seki A, Lu S (2018) Construction of perfectly continuous records of physical properties for darklight sediment sequences collected from the Japan Sea during Integrated Ocean Drilling Program Expedition 346 and their potential utilities as paleoceanographic studies. Prog Earth Planetary Sci 5:23. https://doi.org/10. 1186/s40645-018-0176-7

Irizuki T, Kobe M, Ohkushi K, Kawahata H, Kimoto K (2015) Centennial- to millennial-scale change of Holocene shallow marine environments recorded in ostracode fauna, northeast Japan. Quat Res 84:467-480

Itzstein-Davey F, Athan P, Dodson J, Taylor D, Zheng H (2007a) Environmental and cultural changes during the terminal Neolithic: Qingpu, Yangtze delta, eastern China. The Holocene 17:875-887

Itzstein-Davey F, Athan P, Dodson J, Taylor D, Zheng H (2007b) A sedimentbased record of Lateglacial and Holocene environmental changes from Guangfulin, Yangtze delta, eastern China. The Holocene 17:1221-1231

Jian Z, Wang P, Saito Y, Wang J, Pflaumann U, Oba T, Cheng X (2000) Holocene variability of the Kuroshio Current in the Okinawa Trough, northwestern Pacific Ocean. Earth Planet Sci Lett 184:305-319

Jolly D et al (1998) Biome reconstruction from pollen and plant macrofossil data for Africa and the Arabian peninsula at 0 and 6ka. J Biogeogr 25:1007-1027

Kajita $\mathrm{H}$, Kawahata $\mathrm{H}$, Wang K, Zheng H, Yang S, Ohkouchi N, Utsunomiya M, Zhou B, Zheng B (2018) Extraordinary cold episodes during the midHolocene in the Yangtze delta: interruption of the earliest rice cultivating civilization. Quat Sci Rev 201:418-428

Kariya Y, Aoki K, Takaoka S (2016) A middle Holocene wide-spread tephra, Towada-Chuseri, discovered from a subalpine soil on Mount Aizukomagatake and the Gassan volcano, northern Japan. Quaternary Res (Daiyonki-Kenkyu) 55:237-246 (in Japanese with English abstract)

Kawahata H (2017) Climate/environments which Japanese and Japanese society -climate environmental change and the establishment of Japanese-Japanese society-Japanese culture. Iwanami-Kagaku 87:149-153
Kawahata H, Ishizaki Y, Kuroyanagi A, Suzuki A, Ohkushi K (2017a) Quantitative reconstruction of temperature at Jomon site in the incipient Jomon period in northern Japan and its implication for the production of early pottery and stone arrowheads. Quat Sci Rev 157:66-79. https://doi.org/10.1016/j. quascirev.2016.12.009

Kawahata H, Matsuoka M, Togami A, Harada N, Murayama M, Yokoyama Y, Miyairi Y, Matsuzaki H, Tanaka Y (2017b) Climatic change and its influence on human society in western Japan during the Holocene. Quat Int 440:102-117. https://doi.org/10.1016/j.quaint.2016.04.013

Kawahata H, Minoshima K, Ishizaki Y, Yamaoka K, Gupta LP, Nagao M, Kuroyanagi A (2009a) Comparison of settling particles and sediments at IMAGES coring site in the northwestern North Pacific - effect of resuspended particles on paleorecords. Sediment Geol 222:254-262

Kawahata H, Ohshima H (2002) Small latitudinal shift in the Kuroshio Extension (Central Pacific) during glacial times: evidence from pollen transport. Quat Sc Rev 21:1705-1717

Kawahata $\mathrm{H}$, Yamamoto $\mathrm{H}$, Ohkuchi $\mathrm{K}$, Yokoyama Y, Kimoto $\mathrm{K}$, Ohshima $\mathrm{H}$, Matsuzaki $H$ (2009b) Changes of environments and human activity at the Sannai-Maruyama ruins in Japan during the mid-Holocene Hypsithermal climatic interval. Quat Sci Rev 28:964-974

Kim KR, Cho YK, Kang DJ, Ki JH (2005) The origin of the Tsushima Current based on oxygen isotope measurement. Geophys Res Lett 32:L03602. https://doi. org/10.1029/2004GL021211

Kitagawa J, Yasuda Y (2004) The influence of climate change on chestnut and horse chestnut preservation around Jomon sites in Northeastern Japan with special reference to the Sannai-Maruyama and Kamegaoka sites. Quat Int 123-125:89-103

Kitagawa J, Yasuda Y (2008) The influence of climatic change on chestnut and horse chestnut preservation around Jomon sites in Northeastern Japan with special reference to the Sannai-Maruyama and Kamegaoka sites. Quat Int 123-125:89-103

Kito H (2000) Jinkou kara yomu Nihon no rekishi (history of Japan, based on the population). Koudansya Publishers, Tokyo, pp 1-283 (in Japanese)

Kono Y (2006) Japanese history, Kodanshha Japan, pp 1-229 (in Japanese)

Kosugi Y, Taniguchi Y, Nisida Y, Mizunoe W, Yano K (2009) Archaeology in Jomon Period. Douseisha Publisher, Tokyo. 1-219 (in Japanese)

Kuroyanagi A, Kawahata H, Narita H, Ohkushi K, Aramaki T (2006) Reconstruction of paleoenvironmental changes based on the planktonic foraminiferal assemblages off Shimokita in the northwestern North Pacific. Glob Planet Chang 53:92-107

Kuzmin YV (2006) Chronology of the earliest pottery in East Asia: progress and pitfalls. Antiquity 80:362-371

Liu F, Zhang Y, Feng Z, Hou G, Zhou Q, Zhang H (2010) The impacts of climate change on the Neolithic cultures of Gansu-Qinghai region during the late Holocene Megathermal. J Geogr Sci 20:417-430. https://doi.org/10.1007/ s11442-010-0417-1

Liu Z, Wne X, Brady EC, Otto-Bliesner B, Yu G, Lu H, Cheng H, Wang Y, Zheng W, Ding Y, Edwards RL, Cheng J (2014) Chinese cave records and the East Asia Summer Monsoon. Quaternary Sci Rev 83:115-128

Lucquin A, Gibbs K, Uchiyama J, Saul H, Ajimoto M, Eley Y, Radini A, Heron CP, Shoda S, Nishida Y, Lundy J, Jordan P, Isaksson S, Craig OC (2016) Ancient lipids document continuity in the use of early hunter-gatherer pottery through 9,000 years of Japanese prehistory. In: Proceedings of the National Academy of Science of the United States of America. https://doi.org/10.1073/ pnas.1522908113

Malville JM, Wendorf F, Mazar AA, Schild R (1998) Megaliths and Neolithic astronomy in southern Egypt. Nature 392:488-491

Mayewski PA, Rohling EE, Stager JC, Karlén W, Maasch KA, Meeker LD, Meyerson EA, Gasse F, van Kreveld S, Holmgren K, Lee-Thorp J, Rosqvist G, Rack F, Staubwasser M, Schneider RR, Steig EJ (2004) Holocene climate variability. Quaternary Res 62:243-255

McDougall I, Brown FH, Fleagle JG (2005) Stratigraphic placement and age of modern humans from Kibish, Ethiopia. Nature 433:733-736

Mclntyre A, Be AWH (1967) Modern coccolithophoridae of the Atlantic Ocean 1. Placoliths and crytoliths. Deep-Sea Res Oceanogr Abstr 14:561-597

Nagashima K, Tada R, Toyoda S (2013) Westerly jet-East Asian summer monsoon connection during the Holocene. Geochem Geophys Geosyst 14. https://doi. org/10.1002/2013GC004931

Nakamura T, Taniguchi Y, Tsuji S, Oda H (2001) Radiocarbon dating of charred residues on the earliest pottery. Radiocarbon 43:1129-1138

Nakao S (1976) Saibai-shokubutsu no Sekai (the world of cultivated plants). Chuokoronsha, Tokyo (in Japanese) 
Niimi M (1999) Schematic model for food resources at the Sannai-Maruyama site. $1999^{\text {th }}$ Annual report of the board of Education at Aomori prefecture, pp 58-60

Nishida M (1981) Man-plant relationships in the jomon period and emergence of food production. Bull National Mus Ethnology 6:234-255 in Japanese with English abstract

O'Neil JR, Clayton RN, Mayeda TK (1969) Oxygen isotope fractionation in divalent metal carbonates. J Chem Physics 51:5547-5558

Oba T, Kato M, Kitazato H, Koizumi I, Omura A, Sakai T, Takayama T (1991) Paleoenvironmental changes in the Japan Sea during the last 85,000 years. Paleoceanography 6:499-518

Ogawa Y (1974) The relation between the high saline water in the Japan Sea and Tsushima Current. Fishery Oceanography 24:1-12

Ohkushi K, Suzuki A, Kawahata H, Gupta LP (2003) Glacial-interglacial deep-water changes in the NW Pacific inferred from single foraminiferal $\delta^{18} \mathrm{O}$ and $\delta^{13} \mathrm{C}$. Mar Micropaleontol 48:281-290

Otani K, Terao T (1973) Oceanographic structure of the Mutsu Bay. Bull Fac Fisheries Hokkaido Univ 24:100-131 (in Japanese with English abstract)

Ozawa H, Kamiya T, Itoh H, Tsukawaki S (2004) Water temperature, salinity ranges and ecological significance of the three families of recent cold-water ostracods in and around the Japan Sea. Paleontol Res 8:11-28

Parker AG, Goudie AS, Stokes S, White K, Hodson MJ, Manning M, Kennet D (2006) A record of Holocene climate change from lake geochemical analyses in southeastern Arabia. Quat Res 66:465-476

Peng MS, Zhang YP (2011) Inferring the population expansions in peopling of Japan. PLoS One 6(6):e21509. https://doi.org/10.1371/journal.pone.0021509

Qui S, Zhou W, Leung MYT, Li X (2017) Regional moisture budget associated with drought/flood events over China. Prog Earth Planetary Sci 4:36. https:// doi.org/10.1186/s40645-017-0148-3

Ramsey CB (2009) Bayesian analysis of radiocarbon dates. Radiocarbon. 51:337360. https://doi.org/10.2458/azu_js_rc.v51i1.3494

Reimer PJ et al (2013) IntCal13 and Marine13 radiocarbon age calibration curves 0-50,000 years cal BP. Radiocarbon 55:1869-1887

Rhodes LL, Peake BM, MaCkenzie AL, Warwick S (1995) Coccolithophores Gephyrocapsa oceanica and Emiliania huxleyi (Prymnesiophyceae $=$ Haptophyceae) in New Zealand's coastal waters: characteristics of blooms and growth in laboratory culture. New Zealand Marine Freshwater Res 29: 345-357

Riel S (2008) Climate and agriculture in the ancient Near East: a synthesis of the archaeobotanical and stable carbon isotope evidence. Veg Hist Archaeobotany 17:43-51. https://doi.org/10.1007/s00334-008-0156-8

Sagawa T, Nagahashi Y, Satoguchi Y, Holbourn A, Itaki T, Gallagher SJ, SaavedraPellitero M, Ikehara K, Irino T, Tada R (2018) Integrated tephrostratigraphy and stable isotope stratigraphy in the Japan Sea and East China Sea using IODP sites U1426, U1427 and U1429, expedition 346 Asian monsoon. Prog Earth Planetary Sci 5:18. https://doi.org/10.1186/s40645-018-0168-7

Saito S (2017) The origin of Japanese based upon nuclear genome. Kawade Shobo Shinsho, Tokyo, pp 1-216 ISBN:978-4-309-25372-5 (in Japanese)

Sakitani M (2008) Trip of Japanese for 100,000 years traced by the analysis of DNA. Showado, Kyoto, pp 1-208 (in Japanese)

Sato Y (2001) Paddy rice civilization based upon DNA analysis. NHK books-773, Tokyo, pp 1-227 (in Japanese)

Sato $Y$ (2009) The society of the farming in the Jomon period - what we can understand from DNA analysis ? - PHP research institute, Kyoto, pp 1-218 (in Japanese)

Sato Y, Ishikawa R (2004) The world of the plant at the Sannai-maruyama site -from the DNA archaenological point of view -. Shoukabou, Tokyo, pp 1-158 (in Japanese) ISBN978-4-7853-8765-5

Schornikov El, Zenina MA (2014) Ostracods as indicators of conditions and dynamics of water ecosystems (on the sample of Peter the Great Bay, Sea of Japan). Federal Agency of Research Organizations Russian Academy of Sciences Far Eastern Branch, A.V. Zhirmunsky Institute of Marine Biology, Vladivostok, Dalnauka (in Russian with English abstract)

Scudder RP, Murray RW, Schindlbeck JC et al (2016) Geochemical approaches to the quantification of dispersed volcanic ash in marine sediment. Prog Earth Planetary Sci 3:1. https://doi.org/10.1186/s40645-015-0077-y

Sekine T (2014) Changes in the number of archaeological sites during the Jōmon Period in Aomori Prefecture, northeastern Japan. Quaternary Res (DaiyonkiKenkyu) 53:193-203 (Japanese with English abstract)

Shinoda K (2015) Origin of Japanese based upon DNA. Iwanami modern compendium. Iwanami, Tokyo, pp 1-245 ISBN:9784000291736 (in Japanese)
Shiosawa K (1988) Chestnuts. In: Aiga T (ed) The grand dictionary of horticulture 2. Shogakukan, Tokyo, pp 145-149 (in Japanese)

Simpson EH (1949) Measurement of diversity. Nature 163:688

Stanley DJ, Chen Z, Song J (1999) Inundation, sea-level rise and transition from Neolithic to Bronze Age cultures, Yangtze Delta, China. Geoarchaeology 14:15-26

Stanley JD, Krom MD, Cliff RA, Woodward JC (2003) Short contribution: Nile flow failure at the end of the old kingdom, Egypt: strontium isotopic and petrologic evidence. Geoarchaeology Int J 18:395-402

Staubwasser M, Sirocko F, Grootes PM, Segl M (2003) Climate change at the 4.2 ka BP termination of the Indus valley civilization and Holocene south Asian monsoon variability. Geophysical Res Lett 30:1425. https://doi.org/10.1029/ 2002GL016822

Suzuki Y (2017) Flood history of central Japan during the past 7000 years based on detrital flux to Lake Suigetsu. Ph.D. thesis, the University of Tokyo, pp 1-152

Suzuki Y, Tada R, Yamada K, Irino T, Nagashima K, Nakagawa T, Omori T (2016) Mass accumulation rate of detrital materials in Lake Suigetsu as a potential proxy for heavy precipitation: a comparison of the observational precipitation and sedimentary record. Prog Earth Planetary Sci 3:5. https:// doi.org/10.1186/s40645-016-0081-x

Tada R, Irino T, Ikehara K, Karasuda A, Sugisaki S, Xuan C, Sagawa T, Itaki T, Kubota Y, Lu S, Seki A, Murray RW, Alvarez-Zarikian C, Anderson WT Jr, Bassetti M-A, Brace BJ, Clemens SC, da Costa Gurgel MH, Dickens GR, Dunlea AG, Gallagher SJ, Giosan L, Henderson ACG, Holbourn AE, Kinsley CW, Lee G-S, Lee K-E, Lofi J, Lopes CICD, Saavedra Pellitero M, Peterson LC, Singh RK, Toucanne S, Wan S, Zheng H, Ziegler M (2018) Highresolution and-precision correlation of dark and light layers in the quaternary hemipelagic sediments of the Japan Sea recovered during IODP Expedition 346. Prog Earth Planetary Sci 5:19. https://doi.org/10. 1186/s40645-018-0167-8

Tada R, Murray RW (2016) Preface for the article collection "Land-Ocean linkages under the influence of the Asian monsoon". Prog Earth Planetary Sci 3:24. https://doi.org/10.1186/s40645-016-0100-y

Tada R, Zhen H, Clift PD (2016) Evolution and variability of Asian monsoon and its potential linkage with the Himalayas-Tibetan Plateau. Prog Earth Planetary Sci 3:4. https://doi.org/10.1186/s40645-016-0080-y

Takahashi W, Hiwatari T, Fukushima H, Toratani M, Akano T (1995) Highreflectance waters of possible Coccolithophore blooms in NW Pacific —analysis of 1979-86 Nimbus-7/CZCS data set. Oceanography Japan 4:477486 (in Japanese)

Takei T, Minoura K, Tsukawaki S, Nakamura T (2002) Intrusion of a branch of the Oyashio Current into the Japan Sea during the Holocene. Paleoceanography 17:11-11 10

Takigawa W (2012) Bone archaeology on Emishi and Hayato. Doseisha, Tokyo, pp 1-194

Tsuji S (2001) Life in the Jomon ecosystem. Long route leading to "Japanese". NHK books, pp 112-126 ISBN978-4-14-080625-8

Usoskin IG, Solanki SK, Kovaltsov GA (2007) Grand minima and maxima of solar activity: new observational constraints. Astron Astrophys 471:301-309. https://doi.org/10.1051/0004-6361:20077704

Walker MJC, Berkelhammer M, Bjorck S, Cwynar LC, Fisher DA, Long AJ, Lowe J, Newnham RM, Rasmussen SO, Weiss H (2012) Formal subdivision of the Holocene series/epoch: a discussion paper by a working group of INTIMATE (integration of ice-core, marine and terrestrial records) and the subcommission on quaternary stratigraphy (international commission on stratigraphy). J Quat Sci 27:649-659

Wang K, Hongbo Z, Tada R, Irino T, Zheng Y, Saito K, Karasuda A (2014) Millennial-scale East Asian Summer Monsoon variability recorded in grain size and provenance of mud belt sediments on the inner shelf of the East China Sea during mid-to late Holocene. Quat Int 349:79-89

Wang SW, Huang JM (2006) Variability of dryness/wetness during the midHolocene. Prog Nat Sci 16:1238-1244 (in Chinese)

Wang Y, Cheng H, Edwards RL, He Y, Kong X, An Z, Wu J, Kelly MJ, Dykoski CA, Li $X$ (2005) The Holocene Asian monsoon: links to the changes and North Atlantic climate. Science 308:854-857

Yasuda Y, Fujiki T, Nasu H, Kato M, Morita Y, Mori Y, Kanehara M, Toyama S, Yano A, Okuno M, Jiejun H, Ishihara S, Kitagawa H, Fukusawa H, Naruse T (2004) Environmental archaeology at the Chengtoushan site, Hunan Province, China, and implications for environmental change and the rise and fall of the Yangtze River civilization. Quat Int 123-125:149-158 
Yokoi M (1989) Tochinoki-zoku (Genus Aesculus). In: Aiga T (ed) The grand dictionary of horticulture 3. Shogakukan, Tokyo, pp 390-393 (in Japanese)

Yoneda M, Uno H, Shibata Y, Suzuki R, Kumamoto Y, Yoshida K, Sasaki T, Suzuki A, Kawahata H (2007) Radiocarbon marine reservoir ages in the western Pacific estimated by pre-bomb molluscan shells. Nucl Instrum Method B 259: 432-437

Yoshikawa M, Suzuki S, Tsuji I, Goto K, Murata Y (2006) Vegetation history and activity of people at Sannai-Maruyama site. Vegetation Hist Spec Vol 2:49-82 (in Japanese)

Zenina MA (2009) Influence of anthropogenic pollution on ostracod assemblages of Amurskii Bay, Sea of Japan. Russ J Mar Biol 35:305-312

Zhang Q, Zhu C, Liu T, Jiang T (2005) Environmental change and its impacts on human settlement in the Yangtze Delta, P.R. China. Catena 60:267-277

\section{Publisher's Note}

Springer Nature remains neutral with regard to jurisdictional claims in published maps and institutional affiliations.

\section{Submit your manuscript to a SpringerOpen ${ }^{\circ}$ journal and benefit from:}

- Convenient online submission

- Rigorous peer review

- Open access: articles freely available online

- High visibility within the field

- Retaining the copyright to your article 